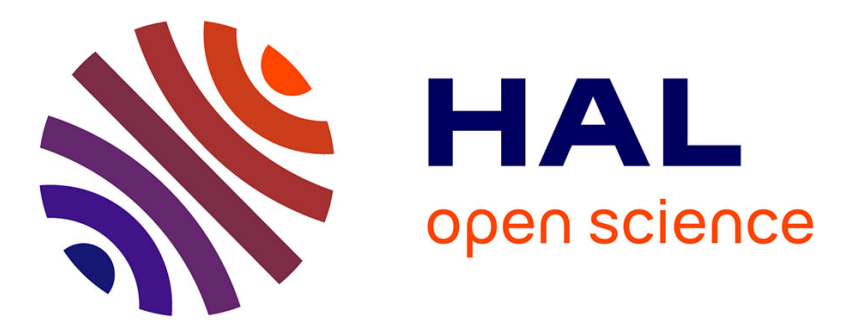

\title{
A stochastic dynamic programming approach to analyze adaptation to climate change - application to groundwater irrigation in India
}

\author{
Marion Robert, Jacques-Eric Bergez, Alban Thomas
}

\section{To cite this version:}

Marion Robert, Jacques-Eric Bergez, Alban Thomas. A stochastic dynamic programming approach to analyze adaptation to climate change - application to groundwater irrigation in India. European Journal of Operational Research, 2017, 265 (3), pp.In Press. 10.1016/j.ejor.2017.08.029 . hal-01608570

\author{
HAL Id: hal-01608570 \\ https://hal.science/hal-01608570
}

Submitted on 26 May 2020

HAL is a multi-disciplinary open access archive for the deposit and dissemination of scientific research documents, whether they are published or not. The documents may come from teaching and research institutions in France or abroad, or from public or private research centers.
L'archive ouverte pluridisciplinaire HAL, est destinée au dépôt et à la diffusion de documents scientifiques de niveau recherche, publiés ou non, émanant des établissements d'enseignement et de recherche français ou étrangers, des laboratoires publics ou privés.

\section{(1) (1) $\$$}

Distributed under a Creative Commons Attribution - NonCommercial - NoDerivatives $\mid 4.0$ 


\section{Accepted Manuscript}

A stochastic dynamic programming approach to analyze adaptation to climate change - application to groundwater irrigation in India

Marion Robert, Jacques-Eric Bergez , Alban Thomas

PII: S0377-2217(17)30760-9

DOI: 10.1016/j.ejor.2017.08.029

Reference: $\quad$ EOR 14648

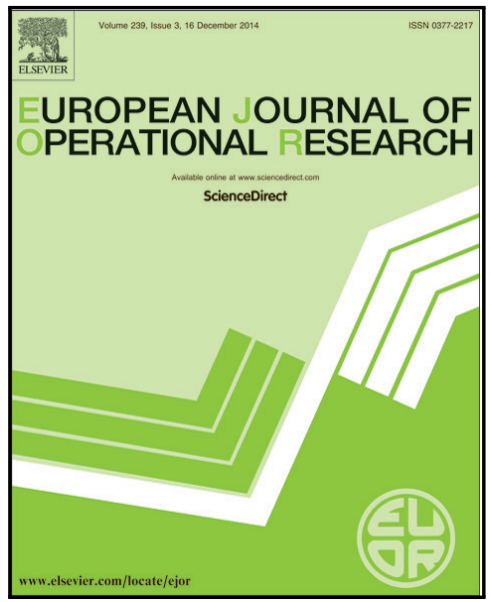

To appear in:

European Journal of Operational Research

Received date:

5 December 2016

Revised date:

16 August 2017

Accepted date:

17 August 2017

Please cite this article as: Marion Robert, Jacques-Eric Bergez, Alban Thomas, A stochastic dynamic programming approach to analyze adaptation to climate change - application to groundwater irrigation in India, European Journal of Operational Research (2017), doi: 10.1016/j.ejor.2017.08.029

This is a PDF file of an unedited manuscript that has been accepted for publication. As a service to our customers we are providing this early version of the manuscript. The manuscript will undergo copyediting, typesetting, and review of the resulting proof before it is published in its final form. Please note that during the production process errors may be discovered which could affect the content, and all legal disclaimers that apply to the journal pertain. 


\section{Highlights}

- Uncertainty and risk significantly influence farmers' decisions

- Farmer decisions are modeled by a stochastic dynamic programming approach

- Farmer decisions concern investment in irrigation, crop choice, irrigation strategy

- Water management policies under climate change scenarios are investigated

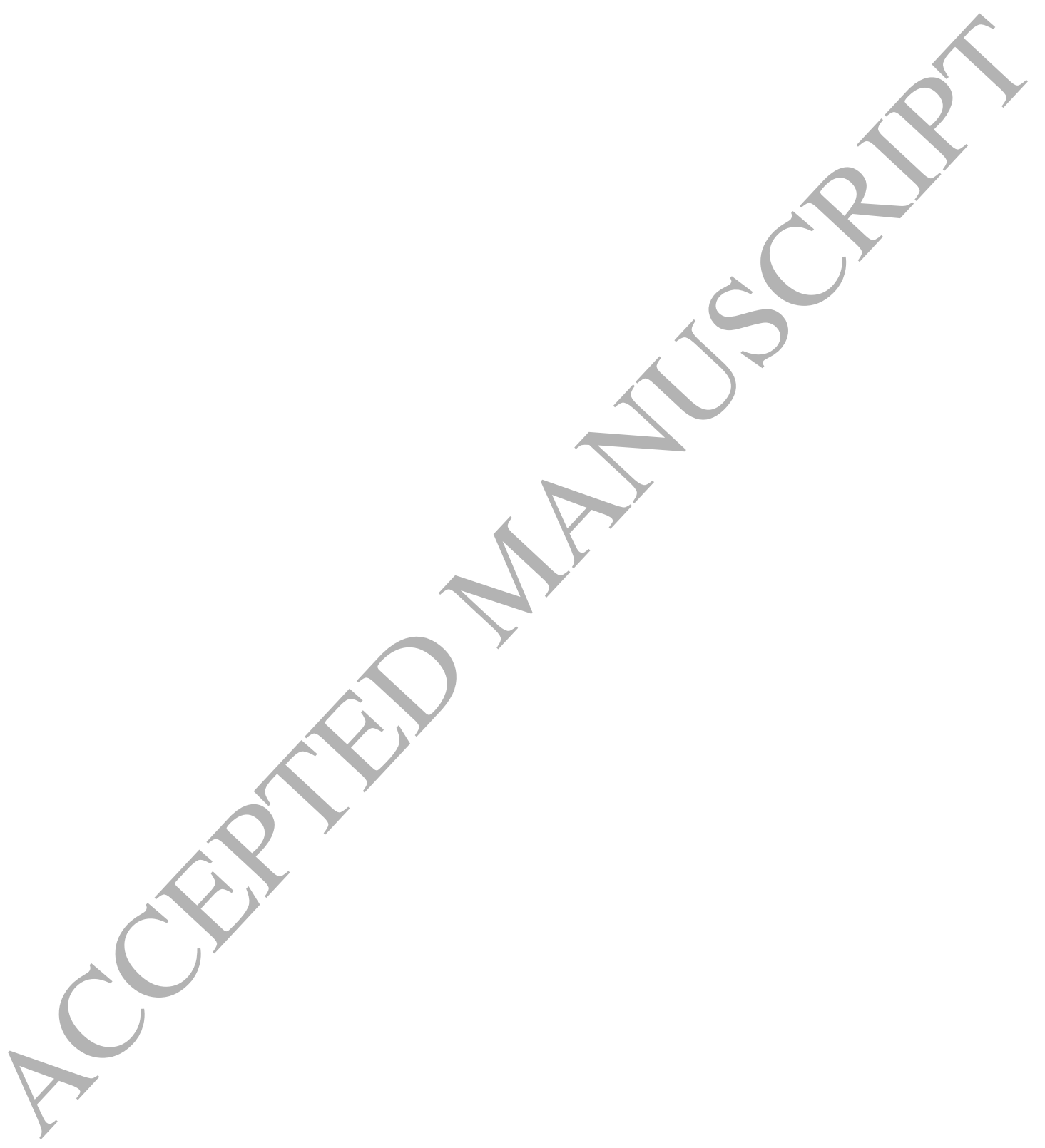




\section{A STOCHASTIC DYNAMIC PROGRAMMING APPROACH TO}

\section{ANALYZE ADAPTATION TO CLIMATE CHANGE - APPLICATION}

\section{TO GROUNDWATER IRRIGATION IN INDIA}

Marion Robert* ${ }^{1}$, Jacques-Eric Bergez ${ }^{1}$ and Alban Thomas ${ }^{2}$

1 AGIR, Université Fédérale de Toulouse, INRA, INPT, F-31326 Castanet-Tolosan

2 Toulouse School of Economics, INRA, University of Toulouse, F-31000 Toulouse, France

Submitted to

European Journal of Operational Research

Scientific article

August 16th, 2017

${ }^{*}$ Corresponding author: (m.robert.marion@gmail.com) 


\section{ABSTRACT}

Agricultural sustainability under climate change is a major challenge in semi-arid countries, mainly because of over-exploited water resources. This article explores short- and long-term consequences of farmers' adaptation decisions on groundwater resource use, under several climate change scenarios. We model farmer decisions on crop choice, investment in irrigation and water application rates, using a stochastic dynamic programming model with embedded year and season decision stages. Several sources of risk are considered that may impact farmer decisions, with poor rainfall affecting crop yield and market prices, while driving crop and borewell failure probabilities. We further investigate the performance of water management policies for groundwater resource conservation. This is achieved through policy simulations from a calibrated version of the stochastic dynamic model, using data from a field survey in the Berambadi watershed, Karnataka state, southern India. The most relevant and novel aspect of our model is the joint consideration of $i$ ) investment decisions about irrigation over a long-term horizon and with the probability of borewell failure, ii) several water management policies, iii) detailed farmers' water practices and the representation of crop choice for each agricultural season with crop failure.

Keywords: (D) OR in agriculture; (I) Stochastic programming; (D) OR in environment and climate change; (D) Strategic planning; (B) Scenarios. 


\section{INTRODUCTION}

Climate change is a significant challenge for sustainable agricultural production in the coming decades, especially since world's food demand is expected to double by the year 2050. Predictions of climate change impacts indicate a reduction in most crop yields under both irrigated and rainfed conditions, an increase in weeds, diseases and pests and changes in crop development and pollination periods (Kahil, Connor and Albiac, 2015).

Agricultural systems in semi-arid areas depend greatly on irrigation and encounter increasing challenges due to climate change (e.g., growing uncertainty about the performance of adaptation strategies to climate change, severe depletion of natural resources), high volatility in crop market prices, rise in energy costs and greater pressure from públic regulation (e.g., agricultural, environmental and health policies). In the Deccan Plateau in India, aided by state policy that subsidizes electricity and improved irrigation technology (e.g., new drilling and submersible pump techniques), the countryside has witnessed the proliferation of individual, electrical pump-driven borewells that abstract water from underground aquifers (Javeed, Sekhar, Bandyopadhyay and Mangiarotti, 2009; Sekhar, Rasmi, Javeed, Gowrisankar and Ruiz, 2006). This led to claims of a "democratization of irrigation", with smallholder farmers accessing irrigation water (Taylor, 2013). However, the low productivity of the aquifer (Dewandel et al., 2010; Perrin, Ahmed and Hunkeler, 2011) and a rapid decline in the groundwater table level led to decreasing borewell yields (Ruiz et al., 2015), implying that groundwater-irrigated agriculture still largely depends on rainfall. Climate variability has increased over the last 50 years in this region (Jogesh and Dubash, 2014). Predictions indicate a $1.8-2.2^{\circ} \mathrm{C}$ increase in temperature by 2030 , and southwestern regions of the state of Karnataka (southern India) are projected to experience a decrease in annual rainfall, especially during the monsoon season (Jogesh and Dubash, 2014). For a region that largely depends on monsoon patterns and winter months to maintain agricultural production, any shift in climate conditions would have a severe impact on natural resources and the local economy. Over the past two decades, rural India has been in the midst of a considerable crisis, illustrated by increasing levels of indebtedness and most tragically exemplified by the wave of farmer suicides, on the Deccan Plateau in particular. The 
need to cope with upcoming debt payments induces farmers to shift towards irrigated cash crops, and gaining control over water access is central to maintain household sustainability. Accessing groundwater may be a solution to provide water for crops on a more regular basis, but this solution must also account for consider social and cultural aspects of farmer indebtedness, including a new temporal horizon for debt repayment and accounting for the risk of failed wells (Taylor, 2013).

In this article, we model adaptive decisions of farmers facing climate change: long-term decisions about investment in borewell irrigation and short-term decisions about cropping systems and the irrigation water application rate for crops. We use a stochastic dynamic model of farmers/decisions to test socio-economic and water management policies under several climate change scenarios. Various policies are considered (subsidizing rainfed crops, reforming subsidized energy for irrigation, a water charge indexed on ambient groundwater level), and their impacts on farmer profit and groundwater level are compared. Each water conservation policy is consídered along with a climate change scenario to evaluate the potential of each policy to mitigate the climate's impact on groundwater level. In the following sections, we first present the farmer's production problem and the data. We then describe the scenarios of climate change and water management policies as well as the simulation results. Finally, we discuss the results and the model to highlight the contribution of the paper to the literature as well as its caveats.

\section{LITERATURE REVIEW ON LONG-TERM FARMER DECISIONS UNDER UNCERTAINTY}

Several fields in the literature have discussed models of farmers' decisions under risk and uncertainty, including irrigation management, ranging from environmental and resource economics to applications of operational research to hydrological issues. Krishnamurthy (2016) presented a theory that clarifies the properties of water management models under risk and uncertainty. Sekhri (2014) explored implications of groundwater irrigation on poverty in rural India using a detailed survey of agricultural wells.

It is essential to consider risk and uncertainty when representing irrigation management and cropping system decisions because of the uncertain nature of water availability for irrigation and crop yield 
resulting from climate conditions. Iglesias and Garrote (2015) provided a literature review on agricultural adaptation to climate change in Europe that describes the possible drivers of adaptation and policy implications.

Regarding the consideration of risk and uncertainty, two main approaches can be found in the agricultural economics literature, depending on whether uncertainty and risk are considered embedded risks or not (Robert et al. 2016). If they are incorporated as non-embedded risk into the objective function, one then assumes that the farmer cannot reduce their impacts a posteriori, in prices, yields and revenues, or in constraints, to represent stochastic resource availability (Briner and Fínger, 2013; Graveline, 2016; McCarl et al. (1999)). However, if uncertainty and risk are incorporated as embedded risks, both risk anticipation and adjustments allow for recourse in the decision.

The main advantage of incorporating risk is to consider stochastio variables such as prices, yields, borewell recharge and water availability for irrigation, which are all related to uncertain weather. In this way, relationships between farm production variables and climate are better considered and represented in models. Fernandez et al. (2016) used stochastic programming to model economic impacts of changes in water availability in small-scale agriculture in the Vergara River Basin, Chile. They applied a calibration method for risk programming models with mean-variance model specification developed by Petsakos and Rozakis (2015) to include risk in the objective function of agricultural models. Blanco-Gutierrez et al. (2013) used a risk-based economic optimization model and a hydrologic water management simulation model to model a vulnerable drought-prone agroecological area in the Middle Guadiana River Basin, Spain. Similarly, Foster et al. (2014) predicted optimal irrigation strategies under variable levels of groundwater supply for irrigated maize production in the Texas High Plains region of the United States, and assessed the limits of existing models for predicting farmers' land and groundwater use decisions.

In discrete stochastic programming, the decision problem is broken down into several decision stages in which new information is available. It can be represented by decision trees. The typical case treated with discrete stochastic programming is cropping pattern planning under weather and/or water uncertainty. For instance, McCarl et al. (1999), Mejías et al. (2004) and Connor et al. (2009) defined 
an initial stage that models the choice of long-term capital investments that remain fixed for several years regardless of annual stochastic variations (water allocation and water price). The second stage addresses short-term (annual) decisions, such as water application rates and land for crops or fallow.

The use of dynamic programming to represent and solve water, nutrient or animal feed management problems in agriculture has a long history. Burt (1993) considered an expected present value problem and from dynamic programming generated a set of sequential decision rules for optimal feed rations and marketed animal weights. Randomness in input and output prices was considered, and properties of the stochastic model were examined for two cases of model application: infinite sequence and single batch. However, no empirical application was presented. Bryant et al. (1993) used a dynamic programming model to explore allocation of irrigation among crops under random climate conditions. During dry periods, a crop can be abandoned temporarily or permanently. Intra-seasonal irrigation rules were considered for maize and sorghum in the Texas High Plains. These authors also used a crop simulator to "simplify" decision rules for crop choice and irrigation application rates. Only two plots of fixed size were set, and a fixed irrigation volume was allocated to only one crop.

Ritten et al. (2010) developed a stochastic dynamic programming model for purposes similar to those of Burt (1993), i.e., to solve for optimal stocking rates under climate change. More precisely, they considered farmers' decisions when rainfall is unknown before the start of the growing season. Farmers maximized the current net value of their land, and the (random) dynamic state variable was vegetation density/When climate scenarios were introduced, profitability decreased as rainfall variability increased compared to the baseline climate.

Maatman et al. (2002) also considered a stochastic programming model to represent farmers' sequential decisions in response to changes in expected rainfall and introduced a food security condition into the problem. More precisely, the farmer's objective was to minimize nutrient deficits at the household level and during several periods (i.e. beginning of the growing season, later in the growing season and after harvesting). They presented one of the first examples in the literature of application of stochastic programming with an explicit subsistence strategy for farmers and adaptation to climate change in an intra-seasonal setting. The method, two-stage stochastic models and multiple- 
recourse models differed, however, from nonlinear stochastic dynamic programming, and no investment decisions in irrigation were considered.

More recently, Livingston, Roberts and Zhang (2015) apply stochastic dynamic programming to evaluating the benefits of corn-soybean crop rotations in the United States (Iowa). Using both experimental plot-level data and historical data on prices and crop yields, they compare short-run vs. long-run decision rules regarding crop choices with stochastic crop prices. They find that farmer decisions under risk aversion are very close to the risk neutrality situation. However, crop choice is less of an issue in their setting, because of the simplified combination they consider between corn and soybean. Risk due to climate change and water availability is not considered neither, their application being focused on nitrogen fertilizer input management.

In the present article, we combine several features of the models discussed above into a model that describes farmer decision rules for groundwater irrigation in more detail, with southern India as an empirical application. Specifically, we consider climate scenarios allowing for changes in rainfall distribution and farmer long-term decisions about investment in irrigation, short-term intra-seasonal decisions about crops and plot size, and water application rates. We develop a dynamic stochastic programming model to study these multiple decisions and improve description of the variety of adaptation pathways to climate change. In the following section, we present the farmer's production problem and the data. The steady state solution to this problem is obtained in terms of optimal control variables, with a convolution-based value iteration algorithm, and an objective function that is calibrated from survey and census data.

\section{METHODS}

\subsection{The farmer's production problem}

Our framework is based on a bio-economic model with season-specific crop choice and agricultural practices, and annual investment decisions on irrigation. We first describe the farmer production 
problem, which is then represented as an application of stochastic dynamic programming with multiple-stage decisions.

\subsubsection{Description of the production problem}

We consider a representative farmer who makes decisions about irrigation and crop choice, while considering consequences of his current decisions on future water availability (because the latter ultimately determines future crop output, hence future profits). The multiple stages of the farmer decision-making process are described as follows:

- At the beginning of the planning horizon, the farmer forms an expectation about several random variables: future climate, future market prices for crops and groundwater availability (for irrigation).

- At the beginning of the year, the farmer decides to invest in irrigation, or to rely on rainfall for the coming year.

- At the beginning of each growing season, the farmer decides which crops to grow on the farm and the associated land area for each plot (plot size varies).

- For each growing season, the farmer decides the irrigation-water application rate for each crop, given total water availability and observed rainfall.

- For each growing season, given the irrigation equipment and selected crops, the farmer follows a set of irrigation rules to obtain the "best" crop yield, conditional on actual climate conditions. Given the irrigation equipment, selected crops and irrigation practices, the farmer can also adjust the proportion of his plots dedicated to crops. For example, when a farmer expects a dry season ahead, a strategy can be to grow multiple crops to diversify the risk of crop failure that is associated with climate.

The farmer's objective is to select the sequence of investment in irrigation equipment and seasonspecific crops that maximizes the discounted stream of future revenue across the planning horizon. Such selection is based on expected rainfall and crop prices, and available water for irrigation, crop costs, crop yields and crop failure probabilities. Farmer decisions can be organized according to two 
time indexes: year for investment in irrigation, and (intra-year) season for crop choice, plot size and irrigation water application rates.

Conditional on irrigation facilities, the farmer maximizes a season-specific sub-profit function with respect to crops, plot size and water application rate for each crop (a proportion of total available water), where total water for crops combines groundwater irrigation and rainfall. Water availability (from expected rainfall and expected groundwater level) triggers the decision to grow particular crops and, during the agricultural season, farmers adjust water for plant needs on a daily (or weekly) basis. Such adjustment is made according to agronomic "rules", and input or output prices and other economic variables are assumed not to influence these short-term decisions.

\subsubsection{A stochastic, dynamic-programming representation for investment decisions in irrigation}

The farmer production problem presented above is fully dynamic because current investment decisions will affect water availability in the future, hence determining future agricultural revenues. It is also stochastic, as farmer profit depends upon future crop prices, rainfall and groundwater availability, which are random variables.

Letting $\pi_{t}\left(I_{t}, W_{t}\right)$ denote profit in year $t$ depending on investment $I_{t}$ (a control variable) and water availability $W_{t}$ (the state variable), the farmer's problem can be represented as the following, general stochastic dynamic programming problem:

$$
\begin{aligned}
& \max _{\left\{I_{t}\right\}} \sum_{t=0}^{\infty} \beta^{t} E\left[\pi_{t}\left(I_{t}, W_{t}\right)\right], \\
& \text { such that } W_{t+1}=f\left(W_{t}, I_{t}, u_{t+1}\right),
\end{aligned}
$$

where $\beta=\frac{1}{1+r}, \beta \in[0,1]$ is a discount factor with $r$ a constant discount rate, and $E($.$) is the$ expectation operator. $f(.,$.$) is a non-stochastic transition function for the state variable, where u_{t+1}$ is a random term; that is, randomness in $W_{t+1}$ originates from the arguments of function $f(.,$.$) only. We$ assume that, since no a priori condition is imposed on the terminal level of water availability or irrigation capital stock, we have an infinite-horizon problem. Maximum year-specific profit $\pi_{t}^{*}\left(I_{t}, W_{t}\right)$ will be discussed below when considering intra-year decisions conditional on variables $I_{t}$ and $W_{t}$. The 
problem (1)-(2) is expressed under the general form of a stochastic dynamic programming problem, and a common approach in the literature is to consider the Bellman principle (Bertsekas, 2011). The Principle of Optimality applied to the discrete-time continuous-state decision model (1)-(2) yields Bellman's recursive functional equation, for time period $\mathrm{t}$ :

$$
V\left(W_{t}\right)=\max _{I_{t}}\left\{\pi_{t}\left(I_{t}, W_{t}\right)+\beta E V\left(W_{t+1}\right)\right\}, \forall t
$$

where $V\left(W_{t}\right)$ is the value function depending on the state variable whose dynamic transition equation is given by (2). Equation (3) represents the solution to the dynamic problem of balancing, for each time period, current benefits with future payoffs, where $E V\left(W_{t+1}\right)=E V\left[f\left(W_{t}, I_{t}, u_{t}\right)\right]$. Note also that the value function is the same for every period because, with an infinite-horizon problem, we are interested in the steady-state solution. For a known value function, the Bellman equation can be solved for the control variable $I_{t}$, given the value of the state variable at any time period $t$.

The main challenge in solving infinite-horizon problems such as (3) is that the value function is unknown and has to be evaluated numerically. Popular numerical methods include linearization, policy iteration and value iteration techniques (see Bertsekas, 2011). In the present paper, we consider the value iteration approach associated with the collocation method (see Miranda and Fackler, 2004), where the value function is approximated through a contraction mapping involving Chebyshev polynomials. If the objective function is bounded and if the discount factor is less than 1 , then there is a unique solution to the dynamic programming problem, following the Contraction Mapping Theorem (see, e.g., Zeidler, 1986). The coefficients of the Chebyshev polynomials are obtained iteratively from the value-function collocation technique, as follows. Denoting by $x$ the order of Chebyshev polynomials for approximating the value function, we can form the following system of $X$ equations with $X$ unknowns evaluated for a given value of the state variable, $W_{x}$ :

$$
\sum_{x=1}^{X} c_{x} \Phi_{x}\left(W_{x}\right)=\max \left\{\pi\left(I, W_{x}\right)+\beta E_{(.)} \sum_{x=1}^{X} c_{x} \Phi_{x}\left[f\left(W_{x}\right)\right]\right\}, x=1, \ldots, X,
$$

where $\Phi_{x}$ and $c_{x}$ is the Chebyshev polynomial of order $x$ and its associated coefficient (to be evaluated), respectively. In the system above, we drop reference to a particular sequence of years ( $t$ and $t+1$ ), because we approximate the value function at the steady state. For this reason, the 
maximization problem is considered for any pair of subsequent values of the state variable, $W_{x}$ and $W^{\prime}=f\left(W_{x}\right)$. The algorithm for solving the problem above starts by selecting a series of $X$ approximation points (the Chebyshev nodes) for which optimal controls are calculated. Given optimal values of the control variables, the Chebyshev coefficients are updated in an intermediate stage, and the process continues until convergence in both optimal control values and Chebyshev coefficients (see Miranda and Fackler, 2004, for details on the numerical implementation of the algorithm). Importantly, the expectation $\mathrm{E}($.$) has to be approximated numerically before implementing the$ iterative algorithm, using for example empirical frequency weights from an empirical distribution. Once the steady state solution is obtained from the algorithm described above, the estimated value function $V($.$) can be used to solve a set of dynamic production problems, given a range of values for$ the state variable $W$ and based on various scenarios (see section 4).

\subsubsection{The intra-year irrigation and crop choice decisions}

We now turn to the short-term, season-specific problem of the farmer, for a given irrigation capital stock $I_{t}$. Consider a representative farmer operating $B$ agricultural plots, on which $C$ crops can be planted. Crops can be grown during two cropping seasons each of duration $L_{\tau}$, where $\tau, \tau=1,2$, is the season index. Farmer decisions depend, among other things, on expected rainfall, which is distributed according to a discrete distribution of rainfall "profiles" $R$ (typically, poor, below average, average, above average or good). Each rainfall regime is associated with an average, season-specific rainfall level denoted $Q_{R, \tau}$, and the probability of occurrence of each rainfall regime is denoted $p r_{R, \tau}$.

Regarding the choice of the cropping system and irrigation practices, crops can be irrigated or rainfed or both, may be grown during both seasons or only one season. When selecting crops, the farmer is assumed to account for the probability of crop failure, denoted $p r_{R, c}$, by expecting to grow another crop $\left(c^{\prime}\right)$ if the first crop fails, and if the remaining time permits to harvest this second crop. Note that the composite subscript of $p r_{R, c}$ includes $R$, to formalize our assumption that the probability of crop failure depends on rainfall. 
For a given $I_{t}$, crop choice and irrigation practices are decided upon by comparing crop-specific and season-specific expected profits, with the expectation based on the rainfall regimes $R$. Letting $\pi_{b c \tau}$ denote the expected profit from crop $c, c=1,2, \ldots, C$, in season $\tau, \tau=1,2$, and on plot $b, b=$ $1,2, \ldots, B$, we can approximate expected profit as the average profit earned over the five rainfall regimes, weighted by the rainfall probability $p r_{R, \tau}$ :

$$
\begin{aligned}
& \pi_{b c \tau} \cong \sum_{i=1}^{5} p r_{R=i, \tau}\left[\left(1-p r_{R=i, c}\right)\left[P_{c \tau}\left(Q_{R=i, \tau}\right) \tilde{Y}_{b c \tau}\left(Q_{R=i, \tau}, W_{b c \tau}\right) \times S_{b}-C_{c}-C_{I}\right]\right. \\
& +\left(p r_{R, c}\right)\left[P_{c^{\prime} \tau}\left(Q_{R=i, \tau}\right) \tilde{Y}_{b c \prime}\left(Q_{R=i, \tau}, W_{b c \prime}\right) \times S_{b}-C_{c^{\prime}}-C_{I}\right] \\
& \text { such that } \sum_{b=1}^{B} \sum_{c=1}^{C} W_{b c \tau} \leq W_{\tau}, \forall \tau,
\end{aligned}
$$

where $Q_{R=i, \tau}$ denotes average rainfall in season $\tau$ under rain regime $i$, crop yield $\tilde{Y}_{b c \tau}$ and crop price $P_{c \tau}$ are stochastic variables that depend on rainfall, $W_{b c \tau}$ is irrigation water applied to crop $c, W_{\tau}$, is irrigation water available during season $\tau$, and $S_{b}$ is the size of the plot (which can be adjusted by the farmer). $C_{l}$ and $C_{c}$ respectively denote irrigation variable cost and crop-specific cost (excluding $C_{I}$ ). Because our problem focuses on irrigation, we consider other crop management practices (e.g. fertilizer, seed, labor) as constant, so that crop cost $C_{c}$ is constant.

From (5), we can define maximum profit at time $t$ as

$$
\pi_{t}^{*}\left(I_{t}, W_{t}\right)=\max _{\left\{\delta_{b c \tau}, S_{b}\right\}} \sum_{b=1}^{B} \sum_{c=1}^{C} \sum_{\tau=1}^{2} \delta_{b c \tau} \pi_{b c \tau}-I_{t}
$$

where $\delta_{b c \tau}=1$ if crop $c$ is grown on plot $b$ in season $\tau$, and 0 otherwise 0 , and $I_{t}$ corresponds to investment cost (see the appendix for the construction of this variable). Equation (6) forms the basis of the intra-year, non-dynamic programming problem, in which $\delta_{b c \tau}$ and $S_{b}$ are discrete (respectively, continuous) decision variables for season $\tau$. There are, however, some extensions to this general model (proposed in subsections 3.1.2 and 3.1.3.) that we need to include, in order to obtain a more detailed description of farmer decisions (see subsection 3.1.4.). 
3.1.4. Accounting for irrigation failure, water availability, and stochastic crop prices

In several settings, investing in irrigation is risky because of possible failure due to averse hydrogeological conditions. For example, drilling a borewell in hard rock aquifers may fail to access groundwater if the borewell does not reach a water fissure. We introduce $p r_{D}$ as the probability of borewell failure (implying that investment in borewell irrigation may well exceed the construction cost of a single borewell), so that the actual construction cost for an operating borewell is inflated by $p r_{D}$ (and is also a function of borewell depth).

Consider now water availability $W_{t}$, the state variable in the basic model (1) - (2), which depends not only on rainfall but also on the farm irrigation capacity. The latter is a function of hydrogeological characteristics such as groundwater table, but also of the time available for pumping (hours of electricity available per day in the season $\tau$ ) and the pump's flow rate. Because the farmer can decide to drill a borewell up to a given depth, and invest in a borewell's pump with a given power, the combination between both forms the actual control variable, which was expressed in a simplified way as $I_{t}$ above. The flow rate of the well provides the maximum water abstraction capacity of the irrigation system and is defined as follows:

$$
F R=h(H P, G, D)\left\{\begin{array}{l}
>\quad \text { if } D>G \\
=0 \text { otherwise }
\end{array}\right.
$$

where $H P, G$ and $D$ respectively denote the borewell pump's horsepower, groundwater table and borewell depth. See the appendix for a definition of function $h$.

The expected water available for irrigation in the season $\tau, W_{\tau}$, is determined from the flow rate, daily power supply ayailable for pumping $\left(A_{\tau}\right)$ and the number of days per season $\left(L_{\tau}\right)$ :

$$
W_{\tau}=F R \times A_{\tau} \times L_{\tau}
$$

Therefore, total irrigation capacity expected for the year is $W=W_{\tau=1}+W_{\tau=2}$ and is distributed among plots according to a season-specific vector of water allocation (denoted $p r_{I}$ ). Note also that, as total water availability depends on random rainfall through runoff and groundwater recharge, this is the justification for the random term $u_{t}$ in the transition function for the state variable, Equation (2). 
Finally, we assume that farmers are "price takers", where crop market prices are likely to depend on climate conditions beyond the farmer's control. We specify each crop price as a reference price $\left(R E F_{c}\right)$ multiplied by crop price elasticity with respect to rainfall. Hence, price decreases by a factor of $\alpha_{i}$ when rainfall shifts to the next rainfall regime $i+1$, and the random price for crop $c$ under the expected rainfall regime $\widetilde{R}_{\tau i}, i=1, \ldots, 5$ is

$$
P_{c \tau}\left(\widetilde{R}_{\tau i}\right)=R E F_{c} \times \alpha_{i}\left(Q_{R=i, \tau}\right)
$$

\subsection{Data}

The model is applied to a representative farmer from the Berambadi watershed in Karnataka, India, who specializes in arable crops, with turmeric, sunflower, marigold, sorghum and maize as major crops grown on two plots. The Berambadi watershed $\left(84 \mathrm{~km}^{2}\right)$ belongs to the Kabini River Basin, which is part of the South Gundal River Basin $\left(816 \mathrm{~km}^{2}\right)$ (southwestern Karnataka). Its climate is dominated by a monsoon regime that generates a strong rainfall gradient with decadal trends, strong inter-annual variability and recurrent droughts (Ruiz et al., 2015). Three seasons regulate the farm cropping system: i) kharif (June to September), the rainy season (monsoon), when most of the cropping area is cultivated; ii) rabi (October to January), the winter season, when most irrigated plots are cultivated; and iii) summer (February to May), the hot and dry season without cultivation.

During kharif, farmers cultivate sunflower, marigold, and maize in rainfed or irrigated conditions and sorghum in rainfed conditions. They also plant irrigated turmeric during this season and harvest it at the end of the next season (rabi). During rabi, farmers grow irrigated maize. If a crop fails during kharif, farmers try to grow maize as a replacement crop to ensure a minimum revenue for the season.

The hard rock aquifer is composed of fissured granite underlain by a 5-20-meter layer of weathered material. In these conditions, using pumps with more horse power is not a solution to increase the amount of irrigation water, due to the low lateral recharge rate, nor is drilling deeper borewells, since this depends on the structure of the fissured granite. In the Berambadi watershed, electricity for irrigation is fully subsidized except for an annual fixed charge of approximately 330 Rs per horse 
power. Therefore, the marginal cost of power supply for irrigation can be considered 0 , even though there are some maintenance costs (discussed above).

Data were obtained from farmer surveys for crop yields and plot size, frequency of crop failure, irrigation and crop costs, while other model variables were calibrated using official, state of Karnataka agricultural census and reports on farm characteristics and minor irrigation schemes (frequency of borewell failure, groundwater level, borewell depth). We surveyed farmers in the watershed in 2014 and 2015. The first survey targeted 27 farmers to obtain detailed data about their practices, in particular their decisions and the process of adapting their decisions. The second survey targeted 680 farmers and obtained general data about farm characteristics and farmers social, economic and agronomic environment. Data from this survey were used to generate a typology of farmers on the watershed based on biophysical factors (e.g. farm location, soil type, ground water accessibility), economic factors (e.g. farm size, labor, equipment), and social factors (e.g., caste, family structure, education, off-farm employment). Additionally, 52 experimental plots were monitored over three years, which provided observed quantitative data about crop production and management. These data supplemented the verbal information farmers provided during surveys. Meteorological data were obtained from a meteorological station and water gauges installed on the watershed. Agricultural prices and production costs were obtained from farmers and from official surveys at the district level from the Indian Ministry of Agriculture and Cooperation (Directorate of Economics and Statistics) and the National Informatics Center (Agricultural Census Division). Data used to calibrate irrigation equipment (investment and operating costs, pump power and purchase price, groundwater level, etc.) were obtained from survey data and from the Minor Irrigation Survey of India, for the State of Karnataka. 


\section{SIMULATIONS AND RESULTS}

Once the value function is estimated from the infinite-horizon problem in section 3.2, dynamic production problems corresponding to various scenarios can be solved from estimated $V($.$) and for a$ range of values for the state variable, $W$. We present in this section scenario-based simulations that are performed over a planning horizon of 30 years, which we assume to be the average lifetime of a borewell.

\subsection{Scenarios}

To evaluate the impact of climate change and water policy reforms on farmers' decisions at the farm level, several scenarios are constructed, which consider both climate and policy changes from the actual situation (used as the benchmark case).

\section{Baseline scenario}

In the baseline scenario, parameters describing the climate, crop marketing conditions (prices and costs) and water pumping conditions (hours of electricity, cost of pumping) are set to average values obtained from farmer surveys.

\section{Climate change scenarios}

Scenario 1 describes the cropping system under climate change conditions in which drier weather (less rainfall) would occur more often. We introduce three additional parameters: 1) $\psi_{1}$ describes the additional weight associated with the rain regimes, in percentage; 2) $\psi_{2}$ indicates more weight on the drier rain regimes when it is equal to two or on the wetter rain regimes when it is equal to one; and 3) $\psi_{3}$ indicates more weight on the first two rain regimes of a given type when it is equal to 2 or to the first rain regime when it is equal to 1 . In all climate change scenarios, we assumed that the proportions 
of both low and below-average rain regimes would increase by $1 \%$ each year (and the proportions of the other rain regimes would decrease by

$$
\frac{1-1.01 \times\left(p r_{R=1}+p r_{R=2}\right)}{\left[p r_{R=3}+p r_{R=4}+p r_{R=5}\right]}
$$

This would increase the chance of drier rain regimes by $30 \%$ after 30 years of simulation (Table 2).

Water management policy scenario: subsidized rainfed crops

Scenario 2 describes the cropping system under climate change conditions and a water management policy that aims to limit groundwater abstraction by encouraging farmers to grow crops under rainfed conditions. The policy provides a subsidy to farmers for each unit of land managed under rainfed conditions. Seven levels of crop subsidy (denoted $K$ ) are tested every 1000 Rs/ha from 1000-7000 Rs/ha, associated only with rainfed crops (Table 2).

Water management policy scenario: electricity usage fee

Scenario 3 describes the cropping system under climate change conditions and a water management policy that aims to limit groundwater abstraction by establishing a user fee for using electricity. The policy sets a user fee for electricity for agricultural purposes. Five levels of fee $C_{E}$ are tested every 0.50 Rs/kWh from 0.50-3.50 Rs/kWh (Table 2).

Water management policy scenario: water charge based on groundwater level

Scenario 4 describes the cropping system under climate change conditions and a water management policy that aims to limit groundwater abstraction by establishing an ambient tax on farmers (Graveline, 2013; Segerson, 1988) based on groundwater level. The policy specifies an ambient water charge based on measured groundwater level, and all farmers located on the same aquifer will have the same tax, regardless of their individual water abstraction. Groundwater level is impacted by total water use of the shared aquifer. The annual tax is applicable when groundwater level has decreased by more than $10 \%$ from its initial depth (at the beginning of the planning horizon) and has decreased between 
the beginning and the end of the given year. In these conditions, the ambient $\operatorname{tax} Q$ is proportional to groundwater depletion when the latter exceeds $\Delta \mathrm{G}=\left(G_{t-1}-G_{t}\right) \times 100 / G_{t}=10 \%$. Nine tax levels are tested with a step of $100 \mathrm{Rs}$, from 200 to 1000 Rs (see Table 2).

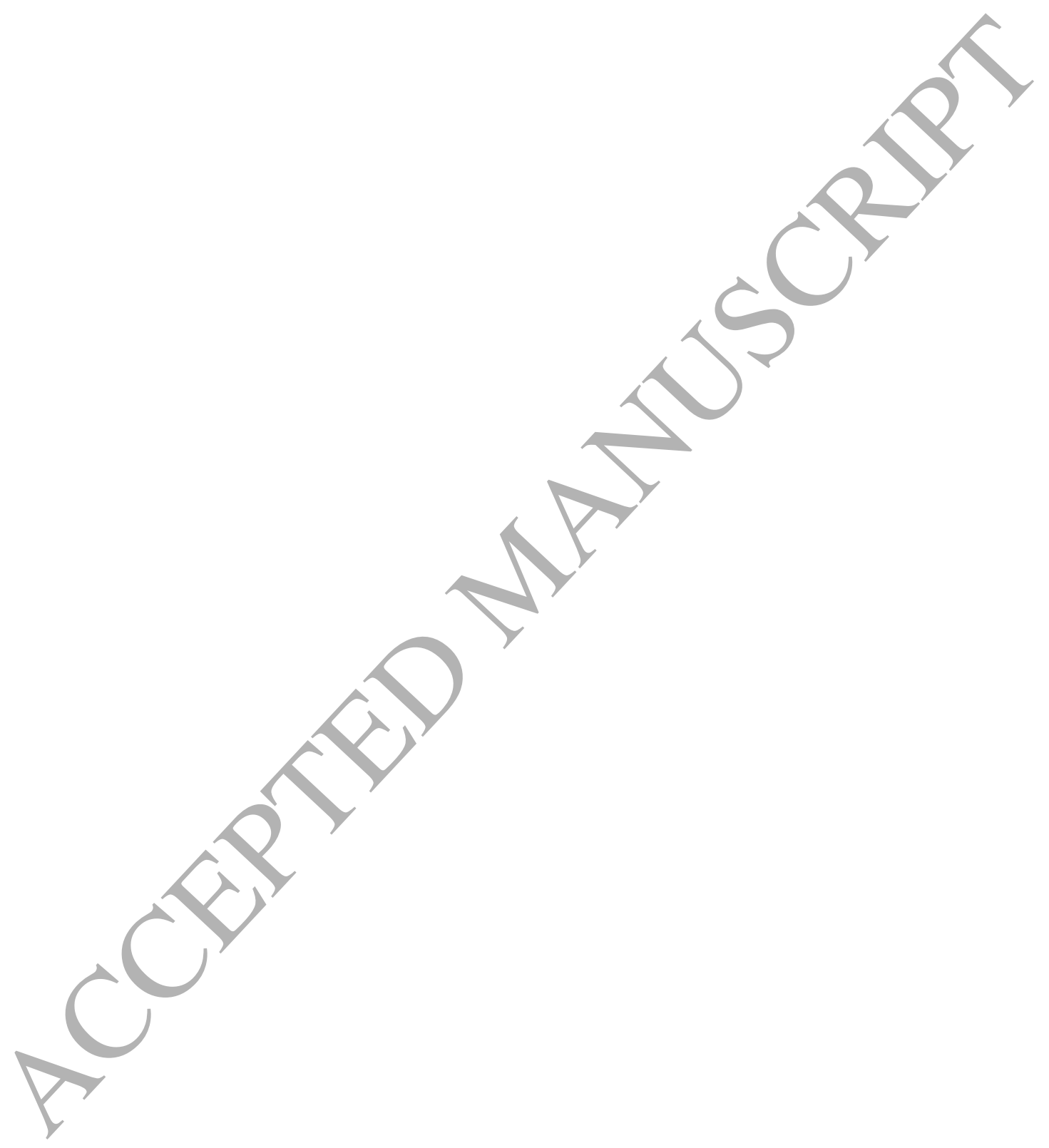


Table 2. Experimental design for policy simulations

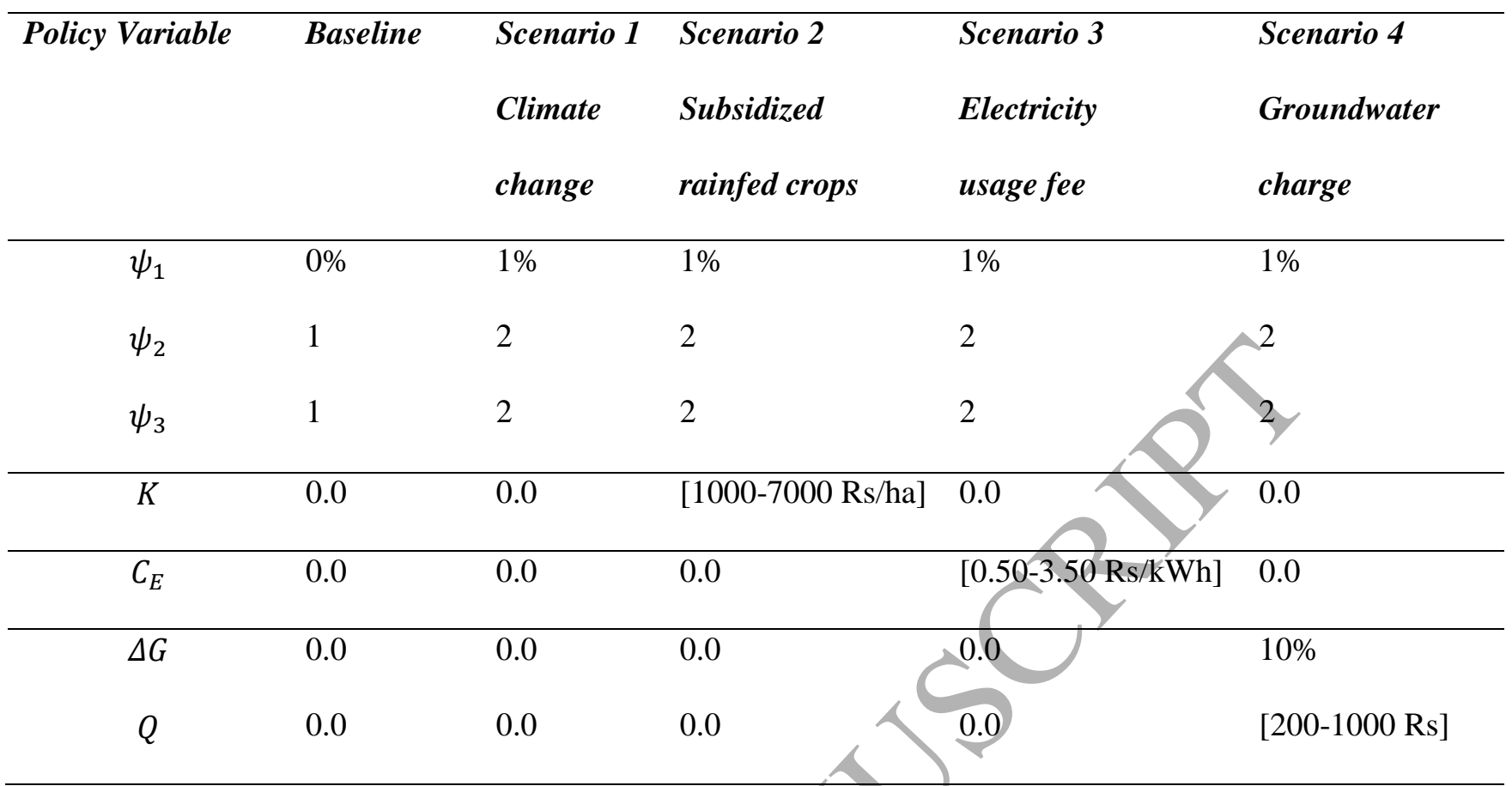

Notes.

$\psi_{1}$ : additional weight associated with the rain regimes (in percent). $\psi_{2}$ : equal to 2 if more weight on drier rain regimes, equal to 1 if more weight on wetter rain regimes. $\psi_{3}$ : equal to 2 if more weight on the first two rain regimes of a given type, or equal to 1 if more weight on the first rain regime.

$K$ is the subsidy rate for rainfed crops (in Rs/ha). $C_{E}$ is a electricity user fee for agricultural purposes. $Q$ is an ambient tax proportional to groundwater depletion when the latter $(\Delta G)$ exceeds $10 \%$. 


\subsection{Results}

The dynamic stochastic problem program described in section 3.1 is solved with $X=10$ as the order of Chebychev polynomials and approximation nodes. The convolution algorithm converged in 111 iterations and took 64 minutes and 47 seconds on a $2 \mathrm{GHz}$ desktop computer. The criterion for convergence is that the sum of squared errors between polynomial coefficients of two consecutive iterations must be less than 0.0001 .

The simulation results depend greatly on the validity and quality of the input assumptions and data. The model's predictions should be interpreted more in terms of trends or in relative terms, rather than in absolute values.

\section{Baseline scenario}

Under the baseline scenario (Figure 1), the farmen invests in a borewell during the first year of simulation. Investing in a borewell allows him to switch from rainfed marigold to irrigated sunflower and turmeric in kharif and from rainfed maize to irrigated maize in rabi. The total amount of pumped water allowed by the borewell flow rate is used each year. The deeper the groundwater table, the lower the pump flow, which requires the farmer to reconsider plot and water allocation between sunflower and turmeric. In the $19^{\text {th }}$ year, the water in the first borewell becomes extremely low due to the low flow rate, and the farmer has to decrease the area of turmeric in favor of sunflower, which decreases profits. The first borewell becomes dry after 20 years of pumping. To maintain this irrigated system, the farmer has no choice but to invest in a second borewell, deeper than the first, at the beginning of the $21^{\text {st }}$ year. Groundwater level decreases from 60 to 116 m.b.g.l. during the planning horizon, while annual farmer profit decreases from around 17,500 Rs in year 2 to $9000 \mathrm{Rs}$ in final year $T$. Increasing groundwater depth by $56 \mathrm{~m}$ over 30 years is an extremely severe scenario. 


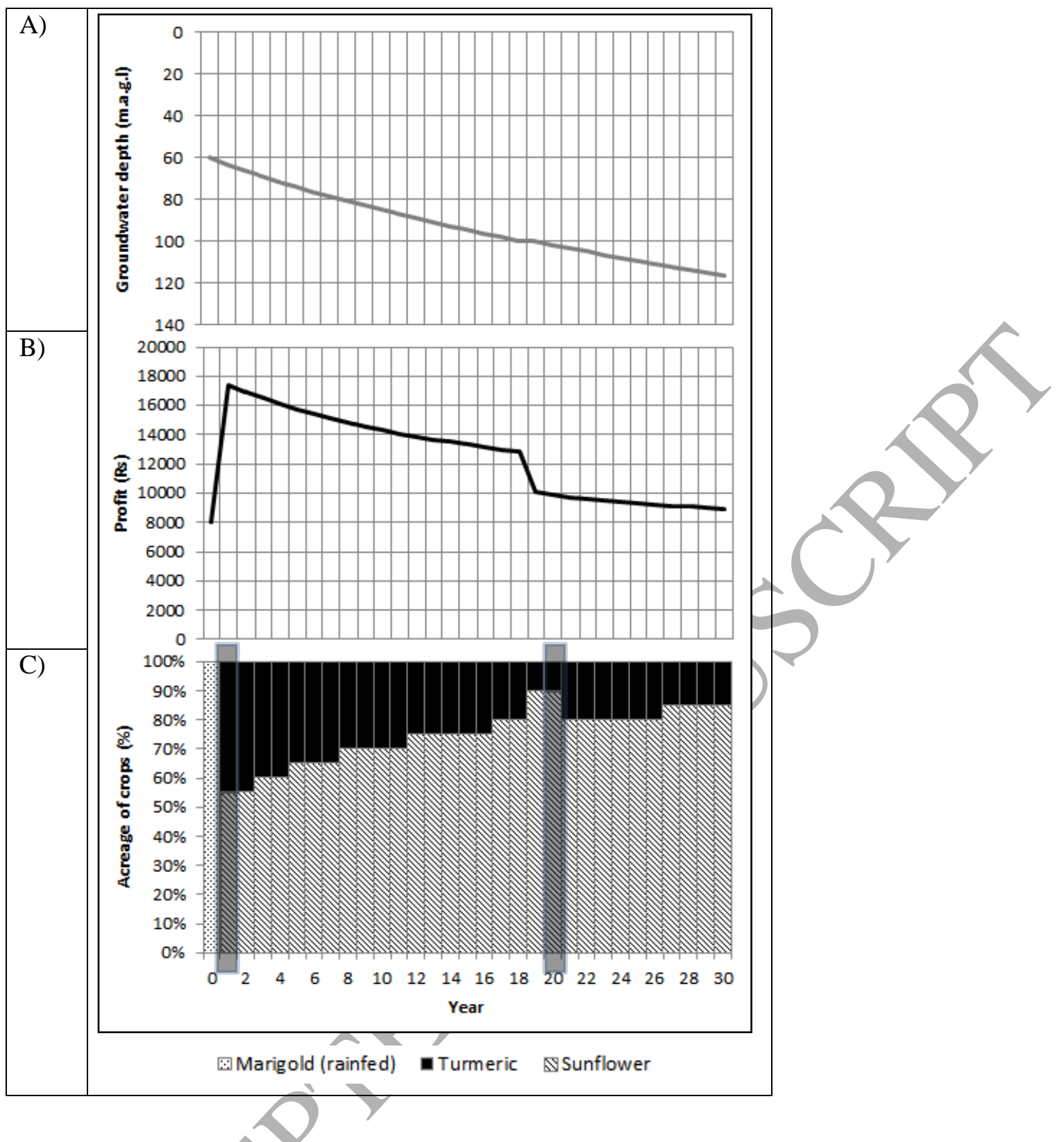

Figure 1. Baseline scenario over the planning horizon (30 years): A) groundwater level, B) farmer profit and C) relative crop area in kharif (irrigated maize replaces irrigated sunflower in rabi) (dark grey columns indicate investment years).

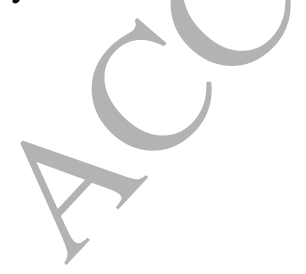




\section{Scenario 1: Climate change alone}

Under the climate change scenario, the farmer's investment behavior is similar to that in the baseline scenario, except that the first borewell becomes dry at the end of the $19^{\text {th }}$ year of pumping, prompting the farmer to drill a second borewell in the $20^{\text {th }}$ year (one year earlier than in the baseline scenario) (Figure 2). The $20^{\text {th }}$ year is disastrous for the farmer because his first borewell is dry and he still has one year of loan repayment left for it, in addition to the new loan obtained for the second borewell. With a higher probability of a dry weather, expected groundwater recharge decreases, prompting the farmer to reduce the area of turmeric in favor of sunflower earlier than in the baseline scenario. Profits are thus lower in this scenario. The groundwater level decreases from 60 to 118 m.b.g.l. during the planning horizon, while annual farmer profit decreases from around 8000 Rs in year 1 to 6500 Rs in final year $T$. As in the baseline case, increasing groundwater depth by $58 \mathrm{~m}$ over 30 years is an extremely severe scenario. 


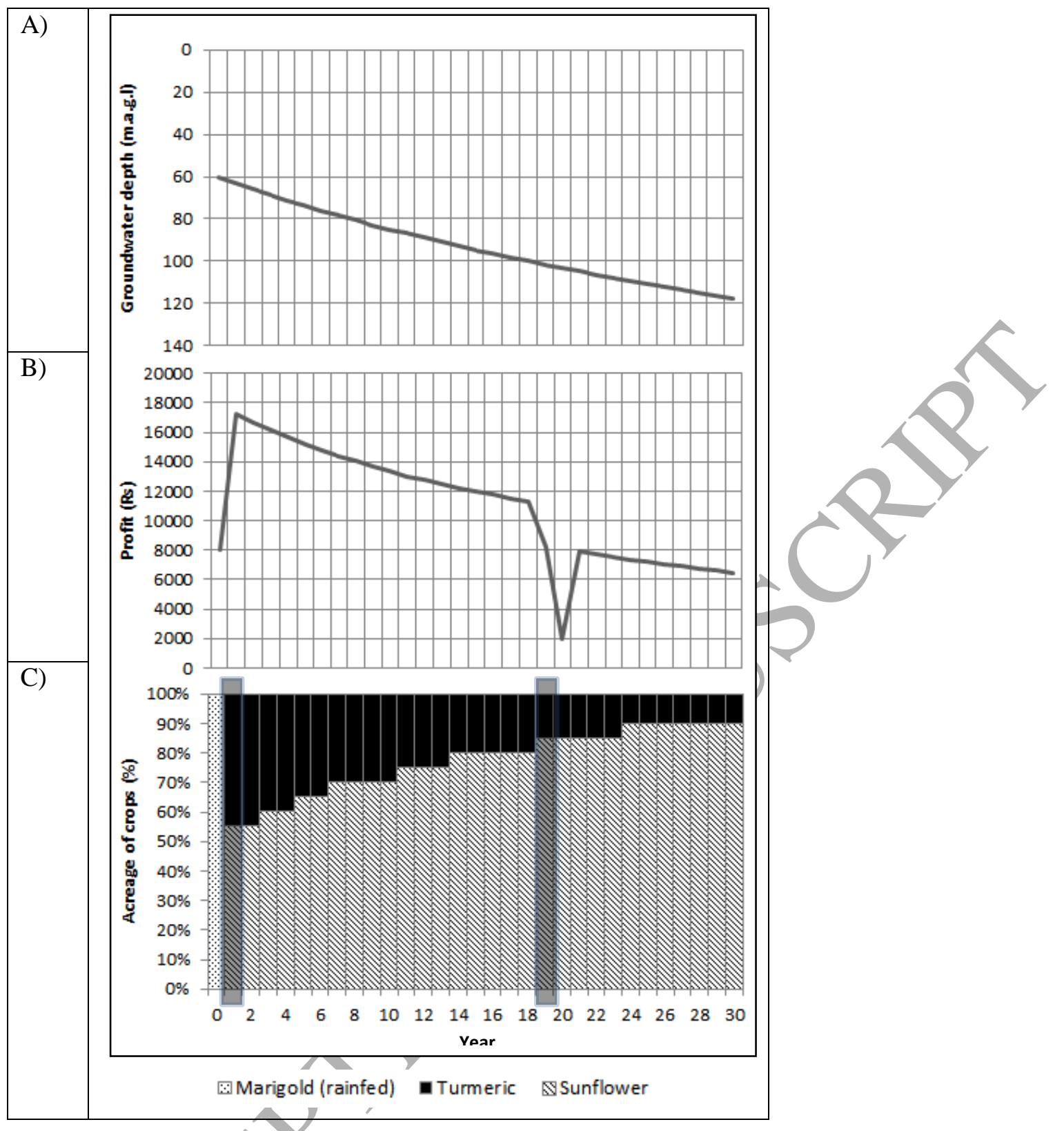

Figure 2. Scenario 1: Climate change alone. A) groundwater level, B) farmer profit and C) relative crop area in kharif (irrigated maize replaces irrigated sunflower in rabi) (dark grey columns indicate investment years).

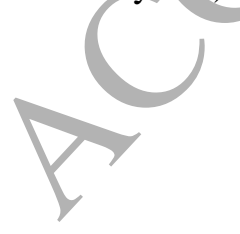




\section{Scenario 2: Climate change and subsidized rainfed crops}

For subsidies up to $3000 \mathrm{Rs} / \mathrm{ha}$, farmer behavior is similar to that in the climate change scenario without a water management policy (Figure 3). The farmer invests in a borewell the first year to grow irrigated turmeric and sunflower in kharif. In the $19^{\text {th }}$ year, instead of growing both turmeric and sunflower, the farmer grows only irrigated sunflower, providing one additional year of pumping (compared to the climate-change-only scenario) before the borewell dries up. Instead of drilling a second borewell, the farmer benefits from the subsidy by growing rainfed marigold. Receiving the subsidy is more profitable than investing in a new borewell. Annual profit in each of the last ten years ranges from $8400-15,900 \mathrm{Rs} / \mathrm{ha}$ with a subsidy of $1000 \mathrm{Rs} / \mathrm{ha}$ of rainfed land, compared to $6400-7900$ Rs/ha under the climate change scenario without a water management policy. From 4000-6000 Rs/ha, irrigated sunflower is replaced by rainfed marigold. All available water is used on turmeric until the 19th year. From there, water use goes from 70 to 65 percent of available water in kharif but stops in rabi season, corresponding to the volume of water recharge from rainfall in kharif and rabi. As a result, the borewell is not even dry after 30 years of pumping. This scenario leads to a depletion of $40 \mathrm{~m}$ of groundwater table height after the 30-year planning horizon. For a subsidy of $7000 \mathrm{Rs} / \mathrm{ha}$ of rainfed crops, the farmer postpones the decision to invest in a borewell until the $15^{\text {th }}$ year. In that year, the groundwater table reaches 45 m.b.g.1., with $15 \mathrm{~m}$ of recharge from rainfall. The groundwater table is high enough to grow turmeric on three-quarters of the land under optimal cropping conditions, and profit from the crop will cover drilling of the borewell and even ensure extra revenue in the first year of investment. Unfortunately, pumping influences groundwater level faster than recharge from rainfall, and water for irtigation rapidly decreases, pushing the farmer to decrease the area of turmeric. Finally, with a subsidy of $7000 \mathrm{Rs} / \mathrm{ha}$, groundwater depth increases by only $27 \mathrm{~m}$ after 30 years, and with a subsidy of $8000 \mathrm{Rs} / \mathrm{ha}$, the farmer does not drill a borewell. Annual farmer profit increases from 8000 Rs in year 1 to between 9000 and 15,000 Rs (depending on the policy) in final year $T$. 


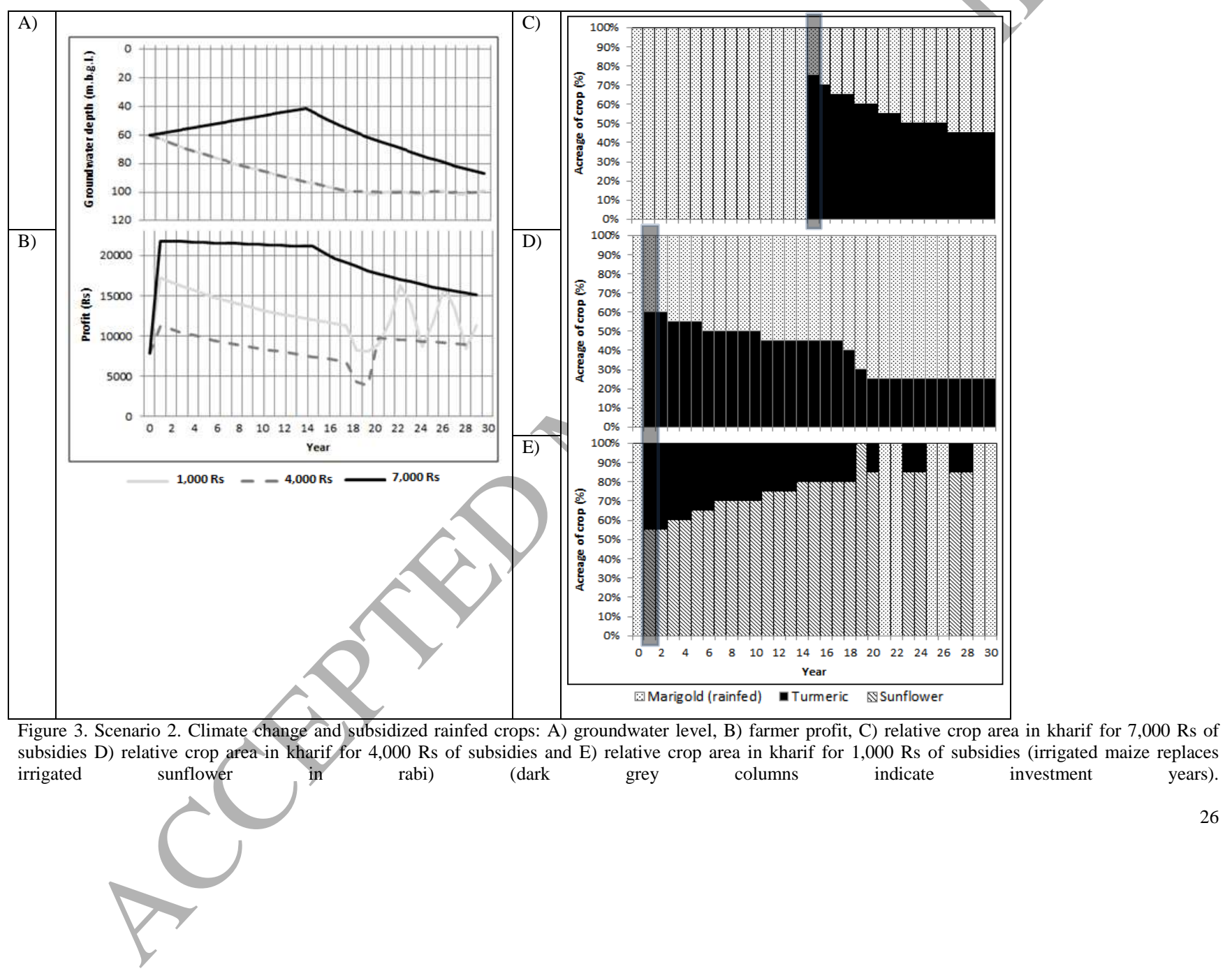


Scenario 3: Climate change and electricity usage fees

When electricity costs $0.50 \mathrm{Rs} / \mathrm{kWh}$, farmers invest in a borewell the first year to irrigate a cropping system consisting of turmeric and sunflower as much as possible during kharif (Figure 4). Pumping at this rate causes the borewell to dry up after 25 years, after which the farmer grows only sunflower and pumps only an amount of water equal to the recharge from rainfall. When electricity costs $1.00-1.50$ $\mathrm{Rs} / \mathrm{kWh}$, farmers drill borewells in the first year and grow maize during rabi under rainfed conditions to use all water during kharif for turmeric and sunflower. At $2.00 \mathrm{Rs} / \mathrm{kWh}$, farmer behavior is similar to that at $1.00-1.50 \mathrm{Rs} / \mathrm{kWh}$, except farmers begin to grow only sunflower in the $19^{\text {th }}$ year and only irrigate as much as the recharge to maintain the borewell level at 82 m.b.g.l. From $2.50 \mathrm{Rs} / \mathrm{kWh}$, farmers delay investing in a borewell, which leads to groundwater table recharge from rainfall. At 2.50 $\mathrm{Rs} / \mathrm{kWh}$, a borewell is drilled in the $6^{\text {th }}$ year, and the groundwater level is maintained at 66 m.b.g.l. from the $14^{\text {th }}$ year, with the farmer growing only sunflower with an amount of water equal to the recharge from rainfall. At $3.00 \mathrm{Rs} / \mathrm{kWh}$, a borewell is drilled in the $14^{\text {th }}$ year, and the groundwater level is maintained at $48 \mathrm{~m}$. b.g.l. from the $18^{\text {th }}$ year. At $3.50 \mathrm{Rs} / \mathrm{kWh}$, the borewell is drilled in the $21 \mathrm{st}$ year, and the groundwater level is maintained at 36 m.b.g.l.

Electricity cost influences profit greatly, as soon as farmers invest in a borewell. Farmers first stop irrigating during rabi and then begin to decrease irrigation during kharif to use only part of their pumping capacity. Annual farmer profit moves from $8000 \mathrm{Rs}$ in year 1 to 5500 and $9500000 \mathrm{Rs}$ (depending on the policy) in final year $T$.

Our results can be compared with Badiani and Jessoe (2011), who estimate the impact of a reduction in electricity subsidies for agriculture. Using district-level historical data on groundwater level and state-level electricity prices, they find that a 1 percent decrease in subsidies would reduce groundwater use by 0.43 percent, with a cost to farmers of about 1.3 percent in revenues. 


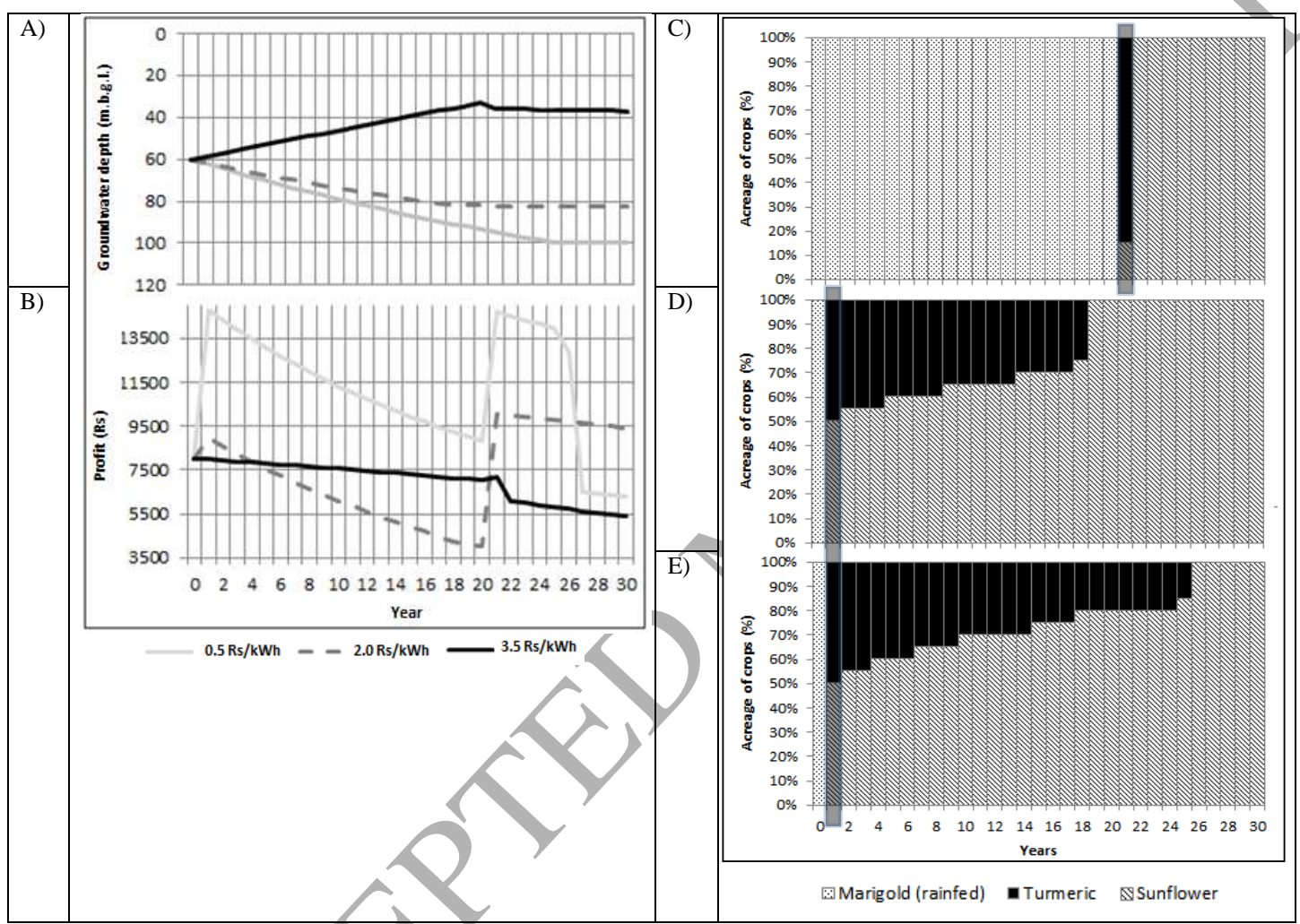

Figure 4. Scenario 3. Climate change and electricity usage fee: A) groundwater level, B) farmer profit, C) relative crop area in kharif for $3.50 \mathrm{Rs} / \mathrm{kWh}$ of fee D) relative crop area in kharif for $2.00 \mathrm{Rs} / \mathrm{kWh}$ of fee and E) relative crop area in kharif for $0.50 \mathrm{Rs} / \mathrm{kWh}$ of fee (irrigated maize replaces irrigated sunflower in rabi) (dark grey columns indicate inyestment years).

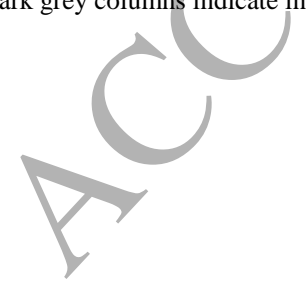


Scenario 4: Climate change and water charge based on groundwater level

Since groundwater level is allowed to decrease slightly, the first decision a famer makes is to drill a borewell in the first year (Figure 5). As long as the groundwater level does not fall "too much", growing irrigated crops is profitable. Once the $10 \%$ threshold is reached, the farmer decreases water abstraction until he pumps only the equivalent of recharge from rainfall during kharif,and stops pumping during rabi so that the groundwater level no longer declines. When this occurs, only irrigated sunflower is planted. For instance, with a water tax at 200 Rs per percentage of groundwater depletion below $10 \%$, the farmer will pump from the borewell until it falls to 79 m.b.g.1. in the $9^{\text {th }}$ year, yielding a maximum tax of approximately 4330 Rs/year. After this year, the farmer/changes the cropping system from turmeric-sunflower to sunflower-sunflower, irrigating with a volume equal to borewell recharge. At 600 Rs, the threshold becomes 70 m.b.g.l. in the $6^{\text {th }}$ year, which yields a maximum tax of 4600 Rs/year. At 1000 Rs, the farmer grows only sunflower starting in the $5^{\text {th }}$ year so that water in the borewell does not decrease below 68 m.b.g.l., which yields a maximum tax of 3330 Rs/year.

Annual farmer profit increases from 8000 Rs in year 1 to 14,000 Rs in final year $T$, but the farmer has to adapt to a long period (from year 5 to year 20), during which profit remains between 8000 Rs and 10,000 Rs a year.

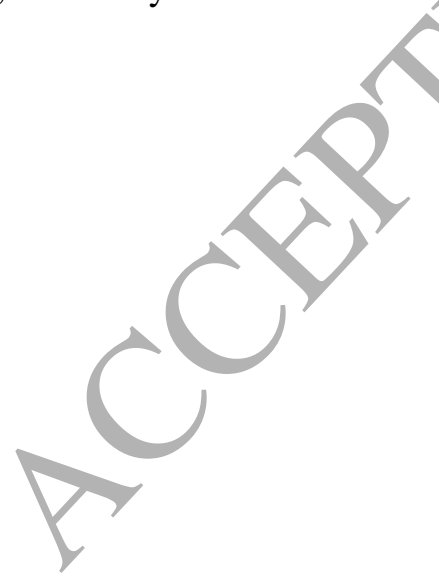




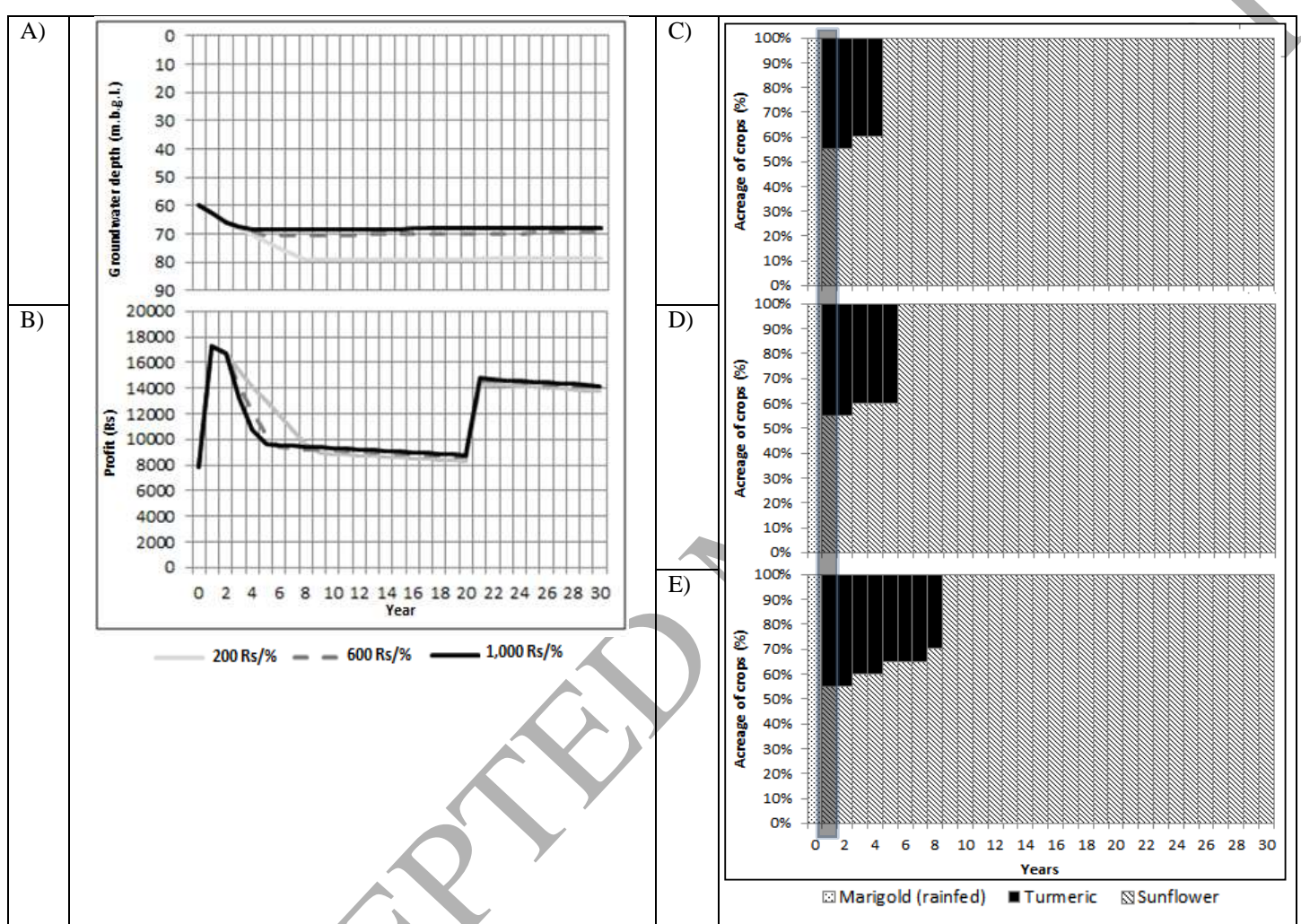

Figure 5. Scenario 4. Climate ehange and water tax based on groundwater level: A) groundwater level, B) farmer profit, C), D) and E): relative crop area in kharif when tax is 1000,600 and 200 Rs (per \% of depletion below $10 \%$ ), respectively.

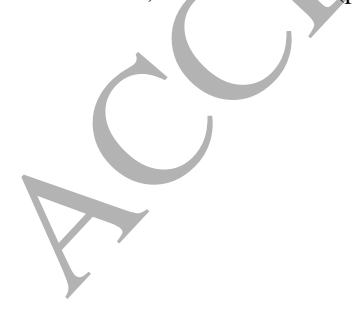




\subsection{Discussion}

Our model tested water management policies aiming at limiting groundwater table depletion. Given the assumptions and simplifications used to describe a representative Indian farmer, it showed that under climate change, a tax on the ambient groundwater level could be an appropriate approach to stabilize groundwater level and limit a decline in farmers' profits. When comparing simulation results associated with our four policies (climate change, subsidized rainfed crops, electricity usage fees, water tax based on groundwater level), we find that all policies succeed fairly well in regulating the decrease in groundwater depletion. However, the impact on farmer profit varies across polices, the introduction of a water tax based on groundwater level (scenario 4) being the most favorable one, followed by subsidized rainfed crops (scenario 2). Scenario 4 with both climate change and a uniform water tax based on observed groundwater level performs also well in terms of groundwater depletion, being second on this criterion after scenario 3 (climate change and electricity usage fee). However, scenario 4 entails a long period (about 15 years), during which profit remains fairly low (between 8,000 Rs and 10,000 Rs a year), implying that a farmer support policy to maintain food security for the agricultural household is necessary. Collecting rainfall water for irrigation using tanks is an ancestral technique in the Berambadi watershed. However, it has been replaced by individual pumping systems. Subsidizing to restore individual or collective tanks may encourage the collection of rainfall water for irrigation usage or direct recharge of the groundwater table.

The contribution of the present study to the literature on irrigation management and agricultural adaptation to climate change in semi-arid countries is the detailed bio-economic representation of farmer decisions under climate change in a dynamic setting. First, we consider investment decisions about irrigation over a long-term horizon, which is similar to the horizon for impacts of climate change and therefore relevant. This helps assess expected impacts of specific climate scenarios (average rainfall intensity and rainfall distribution) and benefits of long-term decisions about irrigation infrastructure, while using the same bio-economic decision model for crop choice and irrigation water application rate. Second, we consider several policies that provide farmers with incentives to manage 
water abstraction in an optimal manner. Third, we combine climate and economic scenarios to explore the robustness of farmer adaptation strategies to changes in the outlook of agricultural markets. Fourth, the description of farmers' water practices (including borewell characteristics and water application rate) is as detailed as the representation of crop choice based on the agricultural season. Most references in the literature focus on only one of these two dimensions.

This accurate description of farmer behavior allows us to explore a wider range of adaptation strategies in response to climate or market events. Our decision model encompasses a significant range of possible farmer decisions, especially during agricultural seasons within a year, in a way that better represents options available to Indian farmers for adapting to climate change. Because our representation of agricultural production technology using groundwater irrigation is more detailed than that of most articles in the literature, it is able to capture implications of farmer decisions for revenue and the groundwater level more accurately. More precisely, the flexibility of the production model, in which plot size, crop choice, crop succession and irrigation application rate can be optimized, is expected to provide a more realistic representation of the sensitivity of farmer revenues to market prices and policy instruments. It is well known (e.g., Chavas, 2012) that, according to the Le Chatelier-Samuelson principle, the sensitivity of an agent's decisions to external pressures is higher if more degrees of freedom exist (for instance, more control variables) (Samuelson, 1961). In its more popular version, this principle states that elasticity of input demand or output supply is lower in the short-term, when all technological dimensions are fixed, than in the long-term, when decisions can include production technology. When models represent production technology as less flexible than it really is, they are likely to under-estimate sensitivity to prices or policy instruments. For instance, when crop choice and plot size are decision variables, an increase in access cost to irrigation is likely to require more adaptation by the farmer than when crop systems are fixed. Additionally, a farmer may be more sensitive to changes in irrigation cost in the long-term, when irrigation capital becomes a control variable, than in the short-term, when only season-specific decisions are feasible. Representing more decision variables is necessary to better evaluate impacts of changes in market variables and the performance of policy instruments that influence farmers' decisions. 
There are several caveats to our analysis. First, the generic nature of the bio-economic and groundwater irrigation model is limited due to the need to calibrate many agricultural and hydrological parameters. Even the representation of irrigation technology is based on hard rock fractured aquifers, and the list of possible crops is also specific to the watershed considered in our case study. The simulations yield solutions that depend greatly on the validity and quality of the input assumptions and data. The model's predictions should be considered more as trends rather than absolute values. However, the structure of the bio-economic model may be used for a wide range of agricultural settings, as long as decisions about crop choice and irrigation are of similar nature, and provided that the model can be calibrated with survey and/or technical data. Second, the model was built to be applicable to other settings and research on investment decisions that influence future decisions about farm management. An important issue regarding farmers' decisions that the model does not address is the importance of subsistence crops. These crops are not grown to be sold but to be consumed by the household. Their cultivation depends on household needs and current stocks of grain. One way to address this limitation is to allocate one plot to a subsistence crop (sorghum), the size of whose plot will be optimized to fill the stock for the coming year. Another possibility is to estimate the cost of buying all subsistence grain at the market to cover family needs and ensure that the farm has enough capital to purchase it each season and each year. Third, we restricted farmers' risk and uncertainty preferences to risk neutrality and non-ambiguity. Farmers are assumed to maximize expected profit based on decision variables in the long- and short-terms, but they are not risk averse and therefore do not adapt production strategies to hedge against production or price risks. Extending our model by considering the expected-utility framework or prospect theory to avoid limitations of the expectedutility framework (e.g., Bocquého, Jacquet and Reynaud, 2013) is certainly feasible, provided risk preferences can be inferred from field surveys or the literature (Ridier, Chaib and Roussy, 2016).

\section{CONCLUSION}

We developed an original dynamic stochastic programming model with recursive programming to study decisions about investment in borewell irrigation and about cropping systems under climate risk. 
We used the model to test socio-economic and water management policies under climate change scenarios. The model was initially developed to address critical issues surrounding groundwater depletion and farming practices in a watershed in southwestern India, but its structure can be used in other agricultural settings. The more complete representation of the production problem, in which irrigation capital stock, plot size, crop choice and irrigation water application rate can all be optimized, is expected to provide a more realistic evaluation of farmer adaptation strategies, while providing a more accurate assessment of the performance of policy instruments.

\section{ACKNOWLEDGEMENTS}

This research was funded by the Indo-French Centre for the Promotion of Advanced Research (CEFIPRA), the INRA flagship program on Adaptation to Climate Change of Agriculture and Forest (ACCAF) and the Doctoral School of the University of Toulouse (EDT). We are grateful to the experts, farmers, survey instructors and trainees who helped collect the data. A special thanks to Tony Raveneau and Ronan Trepos for their help with computer implementation on the INRA Record platform, Toulouse.

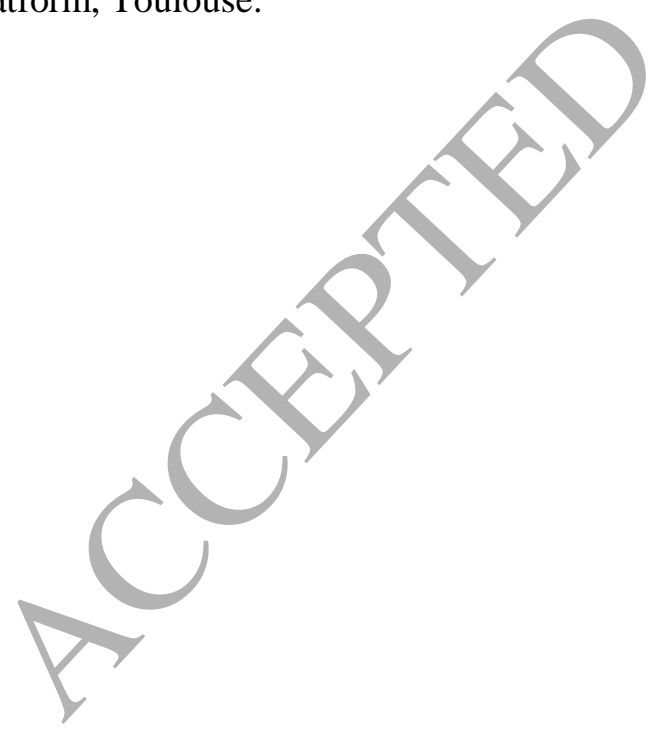




\section{REFERENCES}

Badiani, R. and K.K. Jessoe, 2011. Electricity subsidies for agriculture: Evaluating the impact and persistence of these subsidies in India. Working paper, University of California at Davis.

Bertsekas, D. P. (2011). Dynamic programming and optimal control 3rd edition, volume II. Belmont, MA, USA: Athena Scientific (MA: Athena). Belmont.

Blanco-Gutiérrez, I., Varela-Ortega, C., \& Purkey, D. R. (2013). Integrated assessment of policy interventions for promoting sustainable irrigation in semi-arid environments: A hydro-economic modeling approach. Journal of Environmental Management, 128, 144-160. http://doi.org/10.1016/j.jenvman.2013.04.037

Bocquého, G., Jacquet, F., \& Reynaud, A. (2013). Reversal and magnitude effects in long-term time preferences: Results from a field experiment. Economics Letters, 120(1), 108-111. http://doi.org/10.1016/j.econlet.2013.04.006

Briner, S., \& Finger, R. (2013). The effect of price and production risks on optimal farm plans in Swiss dairy production considering 2 different milk quota systems. Journal of Dairy Sciences, 96(4), 2234-2246.

Bryant, K. J., Mjelde, J. W., \& Lacewell, R. D. (1993). An intraseasonal dynamic optimization model to allocate irrigation water between crops. American Journal of Agricultural Economics, 75(4), 1021. http://doi.org/10.2307/1243989

Burt, O. R. (1993). Decision rules for the dynamic animal feeding problem. American Journal of Agricultural Economics, 75(1), 190. http://doi.org/10.2307/1242967

Chavas, J.-P. (2012). On learning and the economics of firm efficiency: a state-contingent approach. Journal of Productivity Analysis, 38(1), 53-62. http://doi.org/10.1007/s11123-012-0268-0

Connor, J., Schwabe, K., King, D., Kaczan, D., \& Kirby, M. (2009). Impacts of climate change on lower Murray irrigation. Australian Journal of Agricultural and Resource Economics, 53(3), 437-456. http://doi.org/10.1111/j.1467-8489.2009.00460.x

Dewandel, B., Perrin, J., Ahmed, S., Aulong, S., Hrkal, Z., Lachassagne, P., ... Massuel, S. (2010). Development of a tool for managing groundwater resources in semi-arid hard rock regions: application to a rural watershed in South India. Hydrological Processes, 24(19), 2784-2797. http://doi.org/10.1002/hyp.7696

Fernández, F. J., Ponce, R. D., Blanco, M., Rivera, D., \& Vásquez, F. (2016). Water Variability and the Economic Impacts on Small-Scale Farmers. A Farm Risk-Based Integrated Modelling Approach. Water Resources Management, 30(4), 1357-1373. http://doi.org/10.1007/s11269-016$1227-8$

Foster, T., Brozović, N., \& Butler, A. P. (2014). Modeling irrigation behavior in groundwater systems. Water Resources Research, 50(8), 6370-6389. http://doi.org/10.1002/2014WR015620

Graveline, N. (2013). Agricultures' adaptation to water management policies and global change: the interest of economic programming models. mimeo, AgroParis Tech.

Graveline, N. (2016). Economic calibrated models for water allocation in agricultural production: A review. Environmental Modelling \& Software, 81, 12-25. http://doi.org/10.1016/j.envsoft.2016.03.004

Iglesias, A., \& Garrote, L. (2015). Adaptation strategies for agricultural water management under climate change in Europe. Agricultural Water Management, 155, 113-124. http://doi.org/10.1016/j.agwat.2015.03.014

Javeed, Y., Sekhar, M., Bandyopadhyay, S., \& Mangiarotti, S. (2009). EOF and SSA analyses of 
hydrological time series to assess climatic variability and land-use effects: a case study in the Kabini River basin of South India. IAHS-AISH Publication, 167-177.

Jogesh, A., \& Dubash, N. K. (2014). Mainstreaming climate change in state development planning: An analysis of Karnataka's Action Plan on Climate Change. New Delhi.

Kahil, M. T., Connor, J. D., \& Albiac, J. (2015). A stochastic model of irrigation adaption to climate change in southern Europe. In 21st Annual Conference of the European Association of Environmental and Resource Economists (p. 21). Helsinki.

Krishnamurthy, C. K. B. (2016). Optimal management of groundwater under uncertainty: A unified approach. Environmental and Resource Economics. http://doi.org/10.1007/s10640-015-9989-7

Livingston, M., M.J. Roberts and Y. Zhang, 2015. Optimal sequential plantings of corn and soybeans under price uncertainty. American Journal of Agricultural Economics 97(3), 855-878.

Maatman, A., Schweigman, C., Ruijs, A., \& van Der Vlerk, M. H. (2002). Modeling farmers' response to uncertain rainfall in Burkina Faso: A stochastic programming approach. Operations Research, 50(3), 399-414. http://doi.org/10.1287/opre.50.3.399.7749

McCarl, B. A., Dillon, C. R., Keplinger, K. O., \& Williams, R. L. (1999). Limiting pumping from the Edwards Aquifer: An economic investigation of proposals, water markets, and spring flow guarantees. Water Resources Research, 35(4), 1257-1268. http://doi.org/10.1029/1998WR900116

Mejías, P., Varela-Ortega, C., \& Flichman, G. (2004). Integrating agricultural policies and water policies under water supply and climate uncertainty. Water Resources Research, 40(7), W07S03. http://doi.org/10.1029/2003WR002877

Miranda, M. J., \& Fackler, P. L. (2004). Applied computational economics and finance. Cambridge: MIT Press.

Perrin, J., Ahmed, S., \& Hunkeler, D. (2011). The effects of geological heterogeneities and piezometric fluctuations on groundwater flow and chemistry in a hard-rock aquifer, southern India. Hydrogeology Journal, 19(6), 1189-1201. http://doi.org/10.1007/s10040-011-0745-y

Petsakos, A., \& Rozakis, S. (2015). Calibration of agricultural risk programming models. European Journal of Operational Research, 242(2), 536-545. http://doi.org/Calibration of agricultural risk programming models

Ridier, A., Chaib, K., \& Roussy, C. (2016). A Dynamic Stochastic Programming model of crop rotation choice to test the adoption of long rotation under price and production risks. European Journal of Operational Research, 252(1), 270-279. http://doi.org/10.1016/j.ejor.2015.12.025

Ritten, J. P., Frasier, W. M., Bastian, C. T., \& Gray, S. T. (2010). Optimal rangeland stocking decisions under stochastic and climate-impacted weather. American Journal of Agricultural Economics, 92(4), 1242-1255. http://doi.org/10.1093/ajae/aaq052

Robert, M., Thomas, A., \& Bergez, J. E. (2016). Processes of adaptation in farm decision-making models. A review. Agronomy for Sustainable Development. http://doi.org/10.1007/s13593-0160402-x

Ruiz, L., Sekhar, M., Thomas, A., Badiger, S., Bergez, J. E., Buis, S., \& Gascuel, C. (2015). Adaptation of irrigated agriculture to climate change: trans-disciplinary modelling of a watershed in South India. In Hydrological Sciences and Water Security: Past, Present and Future (Proceedings of the 11th Kovacs Colloquium, Paris, France, June 2014) (Vol. 9, p. 2). IAHS Publ.

Samuelson, P. (1961). Foundations of Economic Analysis. Harvard University Press: Cambridge.

Segerson, K. (1988). Uncertainty and incentives for nonpoint pollution control. Journal of Environmental Economics and Management, 15(1), 87-98. http://doi.org/10.1016/0095- 
0696(88)90030-7

Sekhar, M., Rasmi, S. N., Javeed, Y., Gowrisankar, D., \& Ruiz, L. (2006). Modelling the groundwater dynamics in a semi-arid hard rock aquifer influenced by boundary fluxes, spatial and temporal variability in pumping/recharge. Advances in Geosciences, 4, 173-181.

Sekhri, S. (2014). Wells, water, and welfare: The impact of access to groundwater on rural poverty and conflict. American Economic Journal: Applied Economics, 6(3), 76-102. http://doi.org/10.1257/app.6.3.76

Taylor, M. (2013). Liquid Debts: credit, groundwater and the social ecology of the agrarian distress in Andhra Pradesh. Third World Quarterly, 34(4), 691-709.

Zeidler, E. (1986). Nonlinear Functional Analysis and its Applications I: Fixed-Point Theorems. New York: Springer-Verlag.

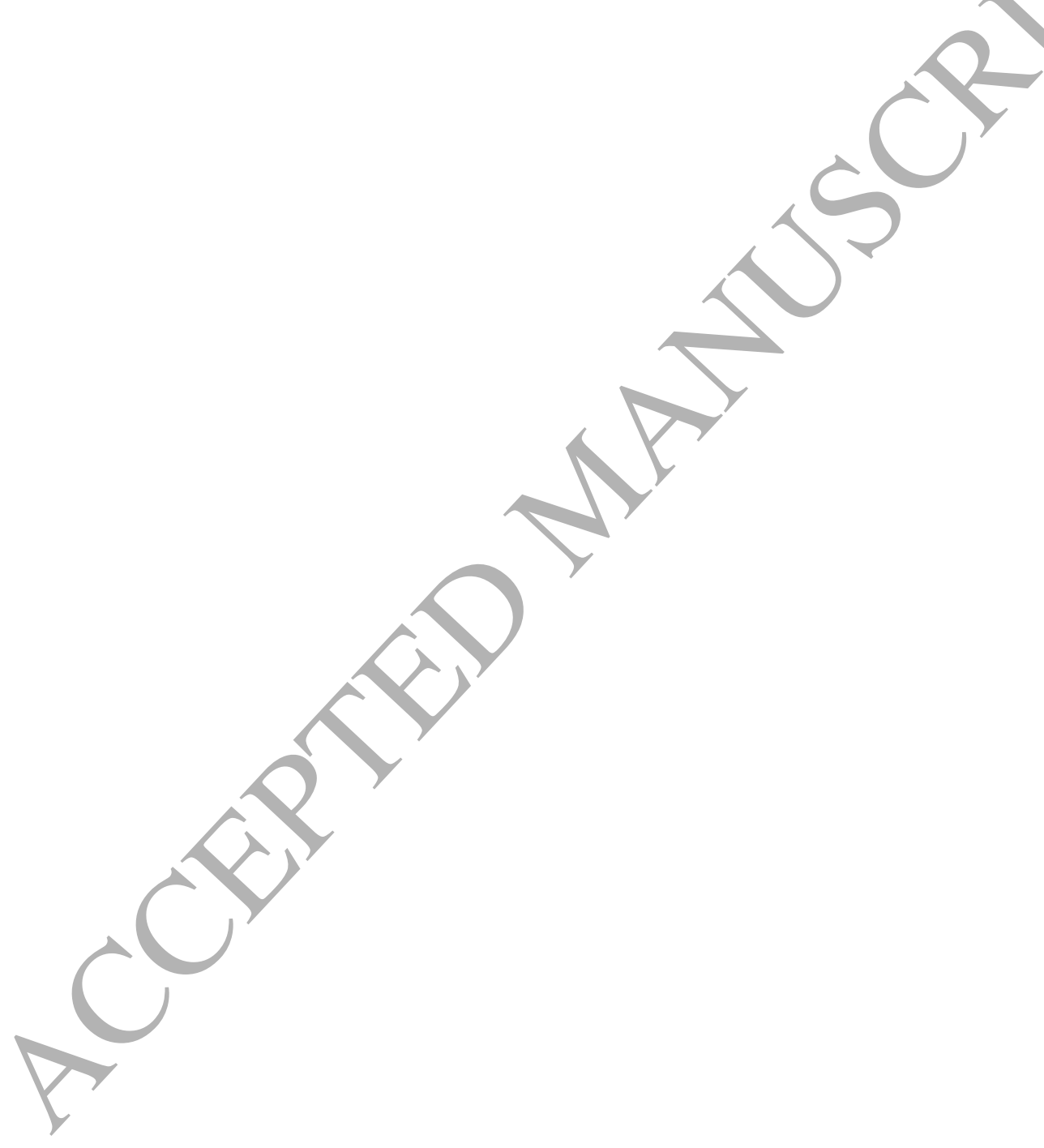




\section{Appendix1. Calibration parameters}

Table 1. Information in parentheses describes either the type of input parameter used in the model or its unit.

\begin{tabular}{|c|c|c|c|c|}
\hline Variable / parameter & Definition, unit & \multicolumn{3}{|c|}{ Value / range } \\
\hline \multicolumn{5}{|c|}{ FARM CHARACTERISTICS } \\
\hline$B$ & Number of agricultural plots & \multicolumn{3}{|l|}{2} \\
\hline$S_{B}$ & Plot size (ha) & \multicolumn{3}{|c|}{ Control variable, between 0 and 2} \\
\hline \multicolumn{5}{|c|}{$\begin{array}{c}\text { SEASON CHARACTERISTICS } \\
\end{array}$} \\
\hline$\tau$ & Season & \multicolumn{3}{|c|}{$1=$ kharif, $2=$ rabi } \\
\hline$L_{\tau}$ & Length of the season (days) & \multicolumn{3}{|c|}{$L_{\tau=1}=180.0 ; L_{\tau=2}=120.0$} \\
\hline \multicolumn{5}{|c|}{ RAINFALL REGIMES } \\
\hline$\tilde{R}$ & \multicolumn{4}{|c|}{$\begin{array}{l}\text { Random rainfall (mm). See also } Q_{R, \tau} \\
\text { below. }\end{array}$} \\
\hline$R$ & \multicolumn{4}{|c|}{$\begin{array}{l}\text { Number of rain regimes } \\
\begin{array}{l}1=\text { =poor, 2=below average, } 3=\text { average, } \\
4=\text { above average, 5=good }\end{array}\end{array}$} \\
\hline \multirow{6}{*}{$\begin{array}{l}Q_{R, \tau}(\text { vector of dimension } \\
R \quad \times \tau)\end{array}$} & \multirow[t]{2}{*}{ Rainfall (mm) } & & $\tau=1$ & $\tau=2$ \\
\hline & & $\mathrm{R}=1$ & 560.50 & 297.82 \\
\hline & & $\mathrm{R}=2$ & 624.62 & 354.55 \\
\hline & & $\mathrm{R}=3$ & 784.33 & 427.19 \\
\hline & & $\mathrm{R}=4$ & 859.60 & 558.00 \\
\hline & & $\mathrm{R}=5$ & 934.60 & 635.50 \\
\hline \multirow{6}{*}{$\begin{array}{ll}p r_{R, \tau} \quad \text { (vector } & \text { of } \\
\text { dimension 5) }\end{array}$} & Distribution of rain regimes, per season & & $\tau=1$ & $\tau=2$ \\
\hline & & $\mathrm{R}=1$ & 0.073 & 0.025 \\
\hline & & $\mathrm{R}=2$ & 0.220 & 0.195 \\
\hline & & $\mathrm{R}=3$ & 0.463 & 0.512 \\
\hline & $y$ & $\mathrm{R}=4$ & 0.220 & 0.195 \\
\hline & & $\mathrm{R}=5$ & 0.024 & 0.073 \\
\hline
\end{tabular}




\begin{tabular}{|c|c|c|}
\hline \multicolumn{3}{|c|}{ WELL CHARACTERISTICS } \\
\hline$I_{t}$ & $\begin{array}{l}\text { Annual investment cost in irrigation } \\
\text { (Rs) }\end{array}$ & Control variable \\
\hline$D$ & Depth of borewell (m) & Control variable, $\{100.0,150.0,200.0\}$ \\
\hline$G$ & Ground water depth (m.b.g.l.) & 60.0 \\
\hline$p r_{D}$ & Probability of well failure & 0.2 \\
\hline$C_{D}$ & Cost of drilling a well (Rs) & See appendix \\
\hline$\sigma$ & Depreciation rate of irrigation equipment & 0.95 \\
\hline$C_{M}$ & Maintenance cost (Rs) & See appendix \\
\hline$F R$ & Flow rate $\left(\mathrm{m}^{3} / \mathrm{h}\right)$ & $\begin{array}{l}\text { See appendix } \\
{[0,1100]}\end{array}$ \\
\hline$S Y$ & Borewell specific yield & 0.021 \\
\hline$D F$ & Borewell discharge factor & 0.054 \\
\hline $\mathrm{RF}$ & $\begin{array}{l}\text { Borewell recharge factor from expected } \\
\text { rainfall }\end{array}$ & 0.10 \\
\hline$W, W^{\prime}$ & Total available water $(\mathrm{mm} / \mathrm{ha})$ & State variable, see appendix \\
\hline$W_{\tau}$ & $\begin{array}{l}\text { Available irrigation water for season } \tau \\
(\mathrm{mm} / \mathrm{ha})\end{array}$ & See appendix \\
\hline$p r_{I}$ & Proportion of available water for irrigation & $\begin{array}{l}\{0.0,0.1,0.2,0.3,0.4,0.5,0.6,0.7,0.8,0.9, \\
1.0\}\end{array}$ \\
\hline \multicolumn{3}{|c|}{ PUMP CHARACTERISTICS } \\
\hline$H P$ & Total pump horse power on the farm (HP) & Control variable, $\{0.0,7.0,14.0\}$ \\
\hline$C_{H P}$ & Pump unit purchase cost (Rs) & See the appendix \\
\hline$A_{\tau}$ & Daily power supply for season $\tau$ & $A_{\tau=1}=4.0, A_{\tau=2}=3.0$ \\
\hline$C_{I}$ & Cost of pumping (Rs) & See the appendix \\
\hline $\mathrm{E}$ & Electric power used for irrigation $(\mathrm{kWh})$ & See the appendix \\
\hline $\mathrm{H}$ & Number of hours of pumping & See the appendix \\
\hline$C_{E}$ & Electricity unit cost (Rs/kWh) & 0.0 \\
\hline
\end{tabular}




\begin{tabular}{|c|c|c|c|c|c|c|c|}
\hline \multicolumn{8}{|c|}{ CROP CHARACTERISTICS } \\
\hline$C$ & Number of crops & \multicolumn{6}{|c|}{$\begin{array}{l}5\{1 \text { [maize], } 2 \text { [sunflower], } 3 \\
\text { [sorghum], } 4 \text { [turmeric], } 5 \text { [marigold] }\}\end{array}$} \\
\hline c' & Crop replacing $\mathrm{c}$ in case of crop failure & \multicolumn{6}{|c|}{1 [maize] } \\
\hline$\tilde{Y}_{b c \tau}$ & Crop yield for crop $\mathrm{c}$ on plot $\mathrm{b}$ for season $\tau$ & \multicolumn{6}{|c|}{ dynamic } \\
\hline$\tilde{P}_{c \tau}$ & Crop market price for crop c for season $\tau$ (Rs/ton) & \multicolumn{6}{|c|}{ dynamic } \\
\hline \multirow[t]{5}{*}{$C_{c}($ vector of dimension $C)$} & \multirow[t]{5}{*}{ Crop cost (Rs/ha) } & \multicolumn{2}{|c|}{$\mathrm{c}=1$} & \multicolumn{4}{|c|}{6058.0} \\
\hline & & \multicolumn{2}{|l|}{$\mathrm{c}=2$} & \multicolumn{4}{|c|}{9642.0} \\
\hline & & \multicolumn{2}{|l|}{$c=3$} & \multicolumn{4}{|c|}{1110.0} \\
\hline & & \multicolumn{2}{|l|}{$c=4$} & \multicolumn{4}{|c|}{45566.0} \\
\hline & & \multicolumn{2}{|c|}{$\mathrm{c}=5$} & \multicolumn{4}{|c|}{23584.0} \\
\hline \multirow{6}{*}{$\begin{array}{l}\operatorname{pr}_{R, c} \text { (vector of dimension } \\
R \times c)\end{array}$} & \multirow[t]{6}{*}{ Crop failure rate } & & $c=1$ & $c=2$ & $\mathrm{c}=3$ & $\mathrm{c}=4$ & $\mathrm{c}=5$ \\
\hline & & $\mathrm{R}=$ & 0.50 & 0.60 & 0.5 & 0.80 & 0.70 \\
\hline & & $\mathrm{R}=$ & 0.30 & 0.40 & 0.3 & 0.50 & 0.50 \\
\hline & & $\mathrm{R}=$ & 0.15 & 0.15 & 0.1 & 0.15 & 0.15 \\
\hline & & $\mathrm{R}=$ & 0.10 & 0.10 & 0.1 & 0.10 & 0.10 \\
\hline & & $\mathrm{R}=$ & 0.05 & 0.05 & 0.0 & 0.05 & 0.05 \\
\hline \multirow{5}{*}{$\begin{array}{l}R E F_{c} \text { (vector of dimension } \\
C)\end{array}$} & \multirow[t]{5}{*}{ Reference crop price (Rs/ton) } & \multirow{2}{*}{\multicolumn{2}{|c|}{$\begin{array}{l}c=1 \\
c=2\end{array}$}} & \multicolumn{4}{|c|}{10436.0} \\
\hline & & & & 29190 & & & \\
\hline & & \multicolumn{2}{|l|}{$c=3$} & \multicolumn{4}{|c|}{10664.0} \\
\hline & & \multicolumn{2}{|l|}{$c=4$} & \multicolumn{4}{|c|}{71810.0} \\
\hline & & \multicolumn{2}{|l|}{$c=5$} & \multicolumn{4}{|c|}{10000.0} \\
\hline \multicolumn{8}{|c|}{ OTHER VARIABLES AND PARAMETERS } \\
\hline$\alpha_{i}$ & Price elasticity factor & \multicolumn{6}{|l|}{0.1} \\
\hline$T$ & Planning horizon for the simulations (years) & \multicolumn{6}{|l|}{30} \\
\hline$t$ & Year & $\{1: T$ & & & & & \\
\hline$r$ & Discount rate & 0.05 & & & & & \\
\hline$\varepsilon_{t}$ & Interest rate & 0.05 & & & & & \\
\hline
\end{tabular}




\section{Appendix2. Model equations}

Irrigation investment cost:

The farmer's annual decisions about investment in irrigation include the decision to drill a new borewell, the well's depth $(D)$ and the power of the (electrical) pump $(H P)$. Assuming the farmer benefits from a $m$-year loan with a fixed interest rate $\varepsilon_{t}$, the annual investment cost $I_{t}$ is

$$
I_{t}=\left(1+\varepsilon_{t}\right)\left(\frac{1}{m}\right)\left(C_{D}+C_{H P}\right)+C_{M},
$$

where $C_{D}, C_{H P}$ and $C_{M}$ are the costs of borewell construction, purchasing the electrical pump and annual borewell maintenance, respectively.

Construction cost of borewells (Rs):

$$
C_{D}=\left(1+100 \times p r_{D}\right) \times\left(486.33 \times D-0.00824 \times D^{2}\right) .
$$

\section{Pump cost (Rs):}

The pump cost $C_{H P}$ depends on the pump's total horse power $H P$ :

$$
C_{H P}=3570 \times H P
$$

Irrigation maintenance cost (Rs):

The irrigation maintenance cost $C_{M}$ is estimated as a function of the potential amount of water $W$ :

$$
C_{M}=6598 \times W^{0.16} .
$$

\section{Cost of groundwater pumping:}

The cost to irrigate crops $\left(C_{I}\right)$ depends on the number of hours of pumping $(H)$, the electric power used (E) and the cost of electricity $\left(C_{E}\right)$ :

$$
C_{I}=H \times E \times C_{E},
$$

where $H=\left(A_{\tau=1} \times L_{\tau=1}+A_{\tau=2} \times L_{\tau=2}\right) \times p r_{I}$.

Flow rate $\left(\mathrm{m}^{3} / \mathrm{h}\right)$ :

The flow rate $(F R)$ is 


$$
F R=79.93 \times G^{-0.728}
$$

where $G$ is the groundwater table. However, the existence of several borewells within a short distance of one another, as occurs among Indian farms, influences total flow rate; thus, maximum water abstraction capacity is not directly proportional to the number of borewells. With more than one borewell, we specify the following total flow rate originating from several borewells (and pumps):

$$
F R=(1+0.38 \times((H P-7) / 7)) \times 79.93 \times G^{-0.728} \quad \text { if } H P>0, \text { and } 0 \text { otherwise }
$$

where $H P$ is the total horsepower of pump(s), assumed equal to 7.0 times the number of wells. The elasticity of flow rate when moving from one to two wells is estimated at 0.38 .

\section{Water availability (state variable):}

Water availability over a specific time-period $(W)$ is considered the state variable of our dynamic model. As discussed in the text, we can equivalently consider the flow rate as the new state variable, because $W$ and $F R$ are connected through variables or parameters that are outside the farmer's control (daily hours of pumping, groundwater table). The flow rate expected for the next time period $\left(W^{\prime}\right)$ is stochastic because it includes borewell recharge $(R F)$ from rainfall $\left(Q_{R, \tau}\right)$, borewell discharge $(D F)$, water pumped for irrigation the past period (W) and the capital stock depreciation rate of the equipment (denoted $\sigma$, assumed equal to 0.05$)$ :

$$
W^{\prime}{ }_{\tau}=p r_{R, \tau} \times \sigma \times 79.93 \times\left[\left(G-Q_{R, \tau} \times R F+G * D F+W_{\tau}\right) / S Y\right]^{-0.728}
$$

\section{Electric power $(\mathrm{kWh}):$}

The electric power used for irrigation $(E)$ is

$$
E=745.7 \times H P .
$$

\section{Crop yield (kg / ha):}

We assume crop yield is a quadratic function of irrigation water distributed to the crop $\left(p r_{I} * W_{\tau}\right)$, but with parameters depending on rainfall regime $\left(e_{c 0}, e_{c 1}, e_{c 2}\right)$, wihich are estimated from a crop growth model.

For $\operatorname{crop} c$ : 


$$
Y_{b c \tau}\left(\tilde{R}_{\tau}, W_{\tau}\right)=e_{c 0}+e_{c 1} p r_{I}\left(\tilde{R}_{\tau}\right) \times W_{\tau}+e_{c 2}\left[p r_{I}\left(\tilde{R}_{\tau}\right) \times W_{\tau}\right]^{2}
$$

where $p r_{I} \in[0,1]$. Note that random rainfall $\widetilde{R}_{\tau}$ is replaced in the computations and the simulations by a weighted sum of rainfall average values $Q_{R, \tau}$, each weighted by probability $p r_{R, \tau}$.

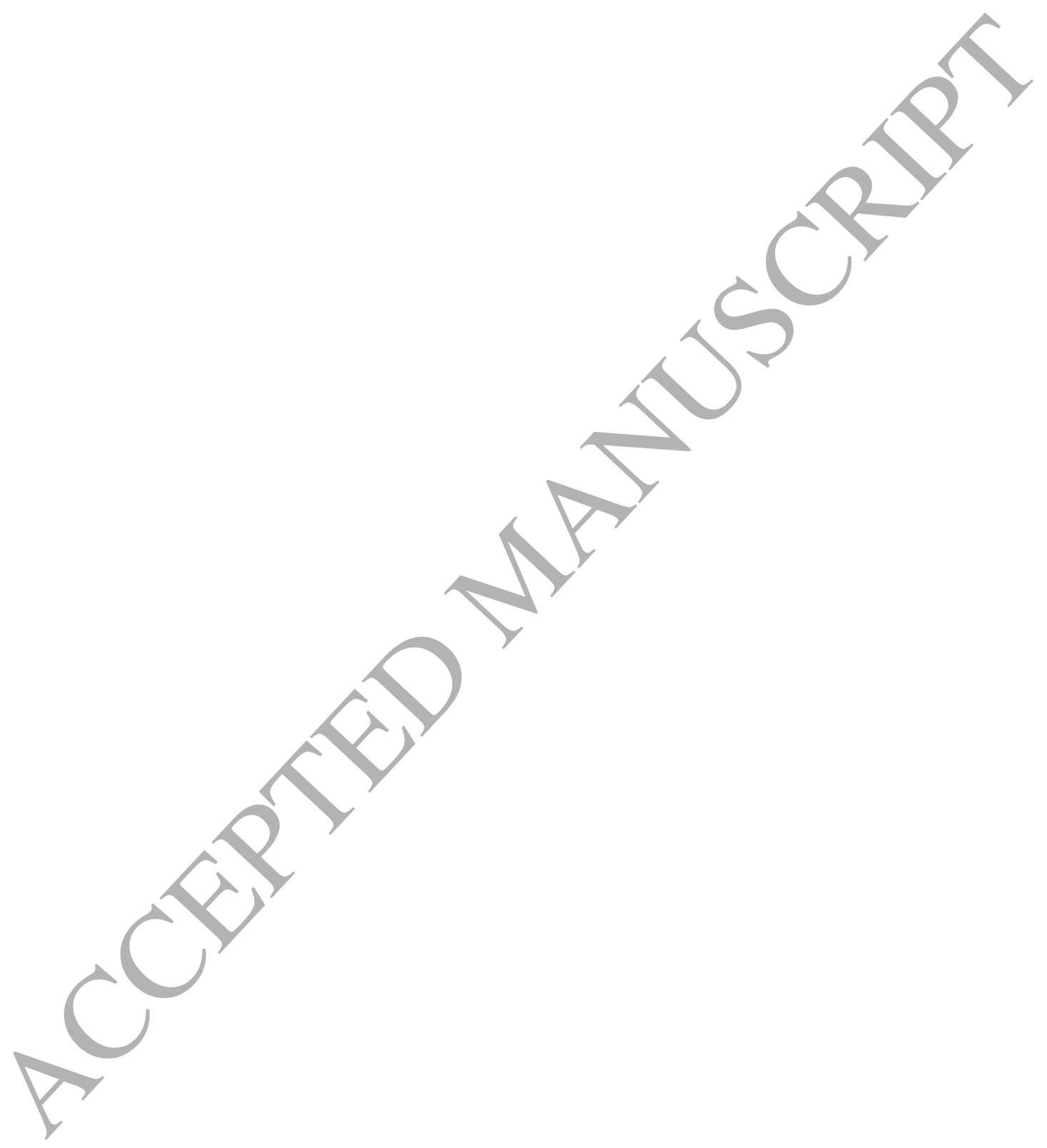

